Prepared in cooperation with the City of Tulsa, Oklahoma

\title{
Estimated Nutrient Concentrations and Continuous Water- Quality Monitoring in the Eucha-Spavinaw Basin, Northwestern Arkansas and Northeastern Oklahoma, 2004-2007
}

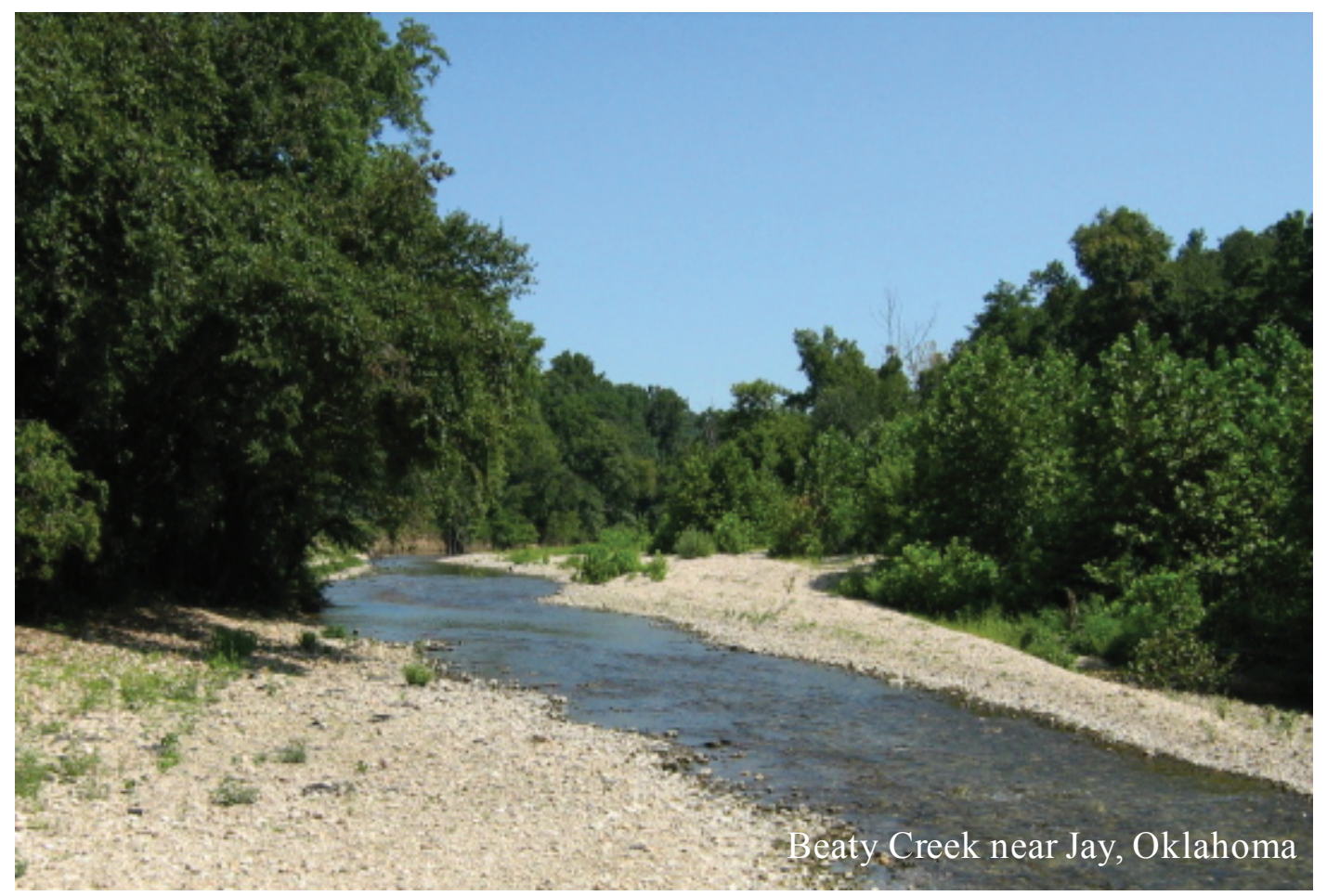

Scientific Investigations Report 2008-5218

Revised February 2009 
Cover: Photograph is Beaty Creek near Jay, Delaware County, Oklahoma, upstream from the streamflow gaging station (07191222), taken March 2008. Photographer: Stephanie Buck, U.S. Geological Survey 


\section{Estimated Nutrient Concentrations and Continuous Water-Quality Monitoring in the Eucha-Spavinaw Basin, Northwestern Arkansas and Northeastern Oklahoma, 2004-2007}

By Victoria G. Christensen, Rachel A. Esralew, and Monica L. Allen

Prepared in cooperation with the City of Tulsa, Oklahoma

Scientific Investigations Report 2008-5218

Revised February 2009 


\title{
U.S. Department of the Interior DIRK KEMPTHORNE, Secretary
}

\section{U.S. Geological Survey \\ Mark D. Myers, Director}

\section{U.S. Geological Survey, Reston, Virginia: 2008 \\ Revised: February 2009}

\author{
This and other USGS information products are available at: \\ http://store.usgs.gov/ \\ U.S. Geological Survey \\ Box 25286, Denver Federal Center \\ Denver, C0 80225 \\ To learn about the USGS and its information products visit http://www.usgs.gov/ \\ 1-888-ASK-USGS
}

\footnotetext{
Any use of trade, product, or firm names is for descriptive purposes only and does not imply endorsement by the U.S. Government.

Although this report is in the public domain, permission must be secured from the individual copyright owners to reproduce any copyrighted materials contained within this report.
}

Suggested citation:

Christensen, V.G., Esralew, R.A., and Allen, M.L., 2008, Estimated nutrient concentrations and continuous waterquality monitoring in the Eucha-Spavinaw basin, northwestern Arkansas and northeastern Oklahoma, 2004-2007: U.S. Geological Survey Scientific Investigations Report 2008-5218, 32 p. (Revised February 2009) 


\section{Contents}

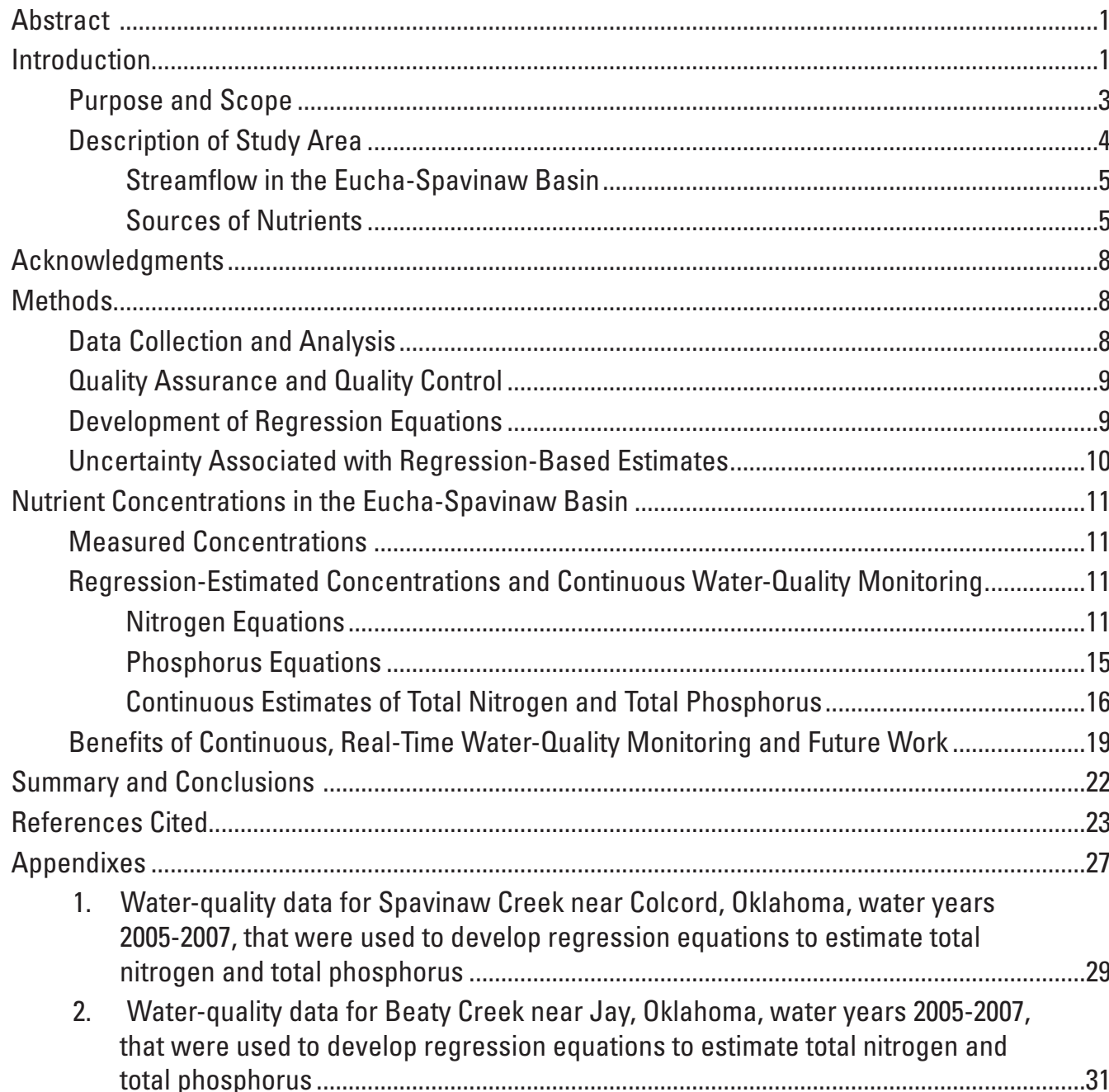

\section{Figures}

1. Map showing the Eucha-Spavinaw basin, Arkansas and Oklahoma, with locations of selected streamflow and water-quality stations......................................

2. Photograph showing algal bloom in Lake Eucha, July $11,2001 \ldots \ldots \ldots \ldots \ldots \ldots \ldots \ldots \ldots \ldots \ldots . . . .4$

3. Map showing comparison of land use in the basins draining to Spavinaw Creek near Colcord, Oklahoma, and Beaty Creek near Jay, Oklahoma, in the EuchaSpavinaw basin, Arkansas and Oklahoma...............................................................

4. Photograph showing a water-quality monitor ..........................................................

5. Graph showing streamflow divided into total flow and base flow, mean of daily mean streamflow for the period of discharge record, and base-flow and runoff 
water-quality samples during Water Years 2005-2007 at (A) Spavinaw Creek near Colcord, Oklahoma, and (B) Beaty Creek near Jay, Oklahoma.

6-7. Plots showing:

6. Comparison of measured and regression-estimated total nitrogen concentrations in water from $(A)$ Spavinaw Creek near Colcord, Oklahoma, and $(B)$ Beaty Creek near Jay, Oklahoma.

7. Comparison of measured and regression-estimated total phosphorus concentrations in water from $(A)$ Spavinaw Creek near Colcord, Oklahoma, and $(B)$ Beaty Creek near Jay, Oklahoma.

8-10. Graphs showing:

8. Comparison of measured and continuous regression-estimated total nitrogen concentrations in water from $(A)$ Spavinaw Creek near Colcord, Oklahoma, and $(B)$ Beaty Creek near Jay, Oklahoma, Water Years 2005-2007.

9. Comparison of measured and continuous regression-estimated total phosphorus concentrations in water from (A) Spavinaw Creek near Colcord, Oklahoma, and (B) Beaty Creek near Jay, Oklahoma, Water Year 2005-2007.

10. Daily mean specific conductance and daily mean streamflow at $(A)$ Spavinaw Creek near Colcord, Oklahoma, and (B) Beaty Creek near Jay, Oklahoma, Water Years 2005-2007.

11. Daily mean turbidity and daily mean streamflow at $(A)$ Spavinaw Creek near Colcord, Oklahoma, and $(B)$ Beaty Creek near Jay, Oklahoma, Water Years 2005-2007.

\section{Tables}

1. Estimates of fertilizer application, number of cattle and calves, and number of broilers and other chickens sold for counties in the Eucha-Spavinaw basin, Arkansas and Oklahoma, 2002

2. Streamflow statistics for continuous water-quality monitoring stations in the Eucha-Spavinaw basin, Arkansas and Oklahoma.

3. Drainage areas, periods of record, and total nitrogen and total phosphorus loads from water-quality stations in the Eucha-Spavinaw basin, Arkansas and Oklahoma, 2002

4. Summary statistics for water-quality properties and constituents of manually collected water samples for Spavinaw Creek near Colcord, Oklahoma, and Beaty Creek near Jay, Oklahoma, October 2004- September 2007.

5. Regression equations for estimated total nitrogen and total phosphorus concentrations for Spavinaw Creek near Colcord, Oklahoma, and Beaty Creek near Jay, Oklahoma, October 2004-September 2007. 


\section{Conversion Factors and Datums}

\begin{tabular}{|c|c|c|}
\hline Multiply & By & To obtain \\
\hline \multicolumn{3}{|c|}{ Length } \\
\hline inch (in.) & 2.54 & centimeter $(\mathrm{cm})$ \\
\hline mile (mi) & 1.609 & kilometer (km) \\
\hline \multicolumn{3}{|c|}{ Area } \\
\hline acre & 4,047 & square meter $\left(\mathrm{m}^{2}\right)$ \\
\hline acre & 0.004047 & square kilometer $\left(\mathrm{km}^{2}\right)$ \\
\hline square mile $\left(\mathrm{mi}^{2}\right)$ & 2.590 & square kilometer $\left(\mathrm{km}^{2}\right)$ \\
\hline \multicolumn{3}{|c|}{ Flow rate } \\
\hline cubic foot per second $\left(\mathrm{ft}^{3} / \mathrm{s}\right)$ & 0.02832 & cubic meter per second $\left(\mathrm{m}^{3} / \mathrm{s}\right)$ \\
\hline million gallons per day (Mgal/d) & 0.04381 & cubic meter per second $\left(\mathrm{m}^{3} / \mathrm{s}\right)$ \\
\hline \multicolumn{3}{|l|}{ 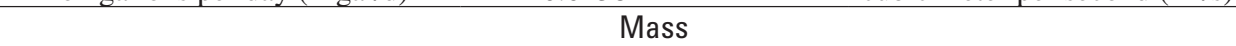 } \\
\hline pound per year (lb/yr) & 0.4536 & kilogram per year $(\mathrm{kg} / \mathrm{yr})$ \\
\hline
\end{tabular}

Temperature in degrees Celsius $\left({ }^{\circ} \mathrm{C}\right)$ may be converted to degrees Fahrenheit $\left({ }^{\circ} \mathrm{F}\right)$ as follows:

${ }^{\circ} \mathrm{F}=\left(1.8 x^{\circ} \mathrm{C}\right)+32$

Temperature in degrees Fahrenheit $\left({ }^{\circ} \mathrm{F}\right)$ may be converted to degrees Celsius $\left({ }^{\circ} \mathrm{C}\right)$ as follows:

${ }^{\circ} \mathrm{C}=\left({ }^{\circ} \mathrm{F}-32\right) / 1.8$

Horizontal coordinate information is referenced to North American Datum of 1983 (NAD 83).

Specific conductance is given in microsiemens per centimeter at 25 degrees Celsius $(\mu \mathrm{S} / \mathrm{cm}$ at $\left.25^{\circ} \mathrm{C}\right)$.

Concentrations of chemical constituents in water are given in milligrams per liter (mg/L).

Method detection limit (MDL)-Minimum concentration of a substance that can be measured and reported with 99-percent confidence that the analyte concentration is greater than zero. It is determined from the analysis of a sample in a given matrix containing the analyte (U.S.

Environmental Protection Agency, 2002). At the MDL concentration, the risk of a false positive is predicted to be less than or equal to 1 percent. 


\title{
Estimated Nutrient Concentrations and Continuous Water-Quality Monitoring in the Eucha-Spavinaw Basin, Northwestern Arkansas and Northeastern Oklahoma, 2004-2007
}

\author{
By Victoria G. Christensen, Rachel A. Esralew, and Monica L. Allen
}

\section{Abstract}

The Eucha-Spavinaw basin is the source of water for Lake Eucha and Spavinaw Lake, which are part of the water supply for the City of Tulsa. The City of Tulsa has received complaints of taste and odor in the finished drinking water because of deteriorating water quality. The deterioration is largely because of algal growth from the input of nutrients from the Eucha-Spavinaw basin. The U.S. Geological Survey, in cooperation with the City of Tulsa, implemented a continuous, real-time water-quality monitoring program in the Eucha-Spavinaw basin to better understand the source of the nutrient loading. This program included the manual collection of samples analyzed for nutrients and the collection of continuous, in-stream data from water-quality monitors.

Continuous water-quality monitors were installed at two existing continuous streamflow-gaging stations-Spavinaw Creek near Colcord, Oklahoma, and Beaty Creek near Jay, Oklahoma, from October 2004 through September 2007.

Total nitrogen concentrations for manually collected water samples ranged from 2.08 to 9.66 milligrams per liter for the water samples collected from Spavinaw Creek near Colcord, Oklahoma, and from 0.67 to 5.12 milligrams per liter for manually collected water samples from Beaty Creek near Jay, Oklahoma. Total phosphorus concentrations ranged from 0.04 to 1.5 milligrams per liter for the water samples collected from Spavinaw Creek near Colcord and from 0.028 to 1.0 milligram per liter for the water samples collected from Beaty Creek near Jay. Data from water samples and in-stream monitors at Spavinaw and Beaty Creeks (specific conductance and turbidity) were used to develop linear regression equations relating in-stream water properties to total nitrogen and total phosphorus concentrations. The equations developed for the Spavinaw and Beaty sites are site specific and only valid for the concentration ranges of the explanatory variables used in the analysis. The range in estimated and measured phosphorus is not representative for the range of historic streamflow at the Beaty site and that regression equation would benefit from more high flow and high turbidity samples. In addition, all three study years had below average annual precipitation for the area, and streamflow was especially low in Water Year 2006. Average nutrient concentrations from October 2004 through September 2007, which were drier than others, may not be a good indication of conditions in future wetter years.

The equations for the Spavinaw and Beaty sites may be used to estimate instantaneous nutrient concentrations, which can be used to compute loads and yields in real time in order to better characterize the effect of land-management practices in these watersheds on the transport of nutrients to Lake Eucha and Spavinaw Lake. The methods used in this study show promise for monitoring future effectiveness of implemented best management practices, development and monitoring of total maximum daily loads, early detection of taste-and-odor occurrences, and to anticipate treatment needs for water suppliers.

\section{Introduction}

The Eucha-Spavinaw basin is primarily in Benton County in northwestern Arkansas and in Delaware County in northeastern Oklahoma (fig. 1). Construction of Lake Eucha and Spavinaw Lake was completed in 1954 and 1924, respectively (Tortorelli, 2006) to provide wildlife habitat, recreational opportunities, and a reliable municipal water supply for the City of Tulsa. Lake Eucha receives water from Spavinaw Creek, Beaty Creek, Brush Creek, Rattlesnake Creek, Dry Creek, and a few minor tributaries upstream from Spavinaw Lake. Lake Eucha serves as an environmental and hydrologic buffer to Spavinaw Lake (City of Tulsa, 2008). The water flows from Spavinaw Lake to the City of Tulsa through a series of 60-mile long pipelines (Tortorelli, 2006). The water serves about 600,000 residents in the Tulsa metropolitan area and northeastern Oklahoma (Bob Brownwood, Water Supply Manager, City of Tulsa, written commun., July 2008). 


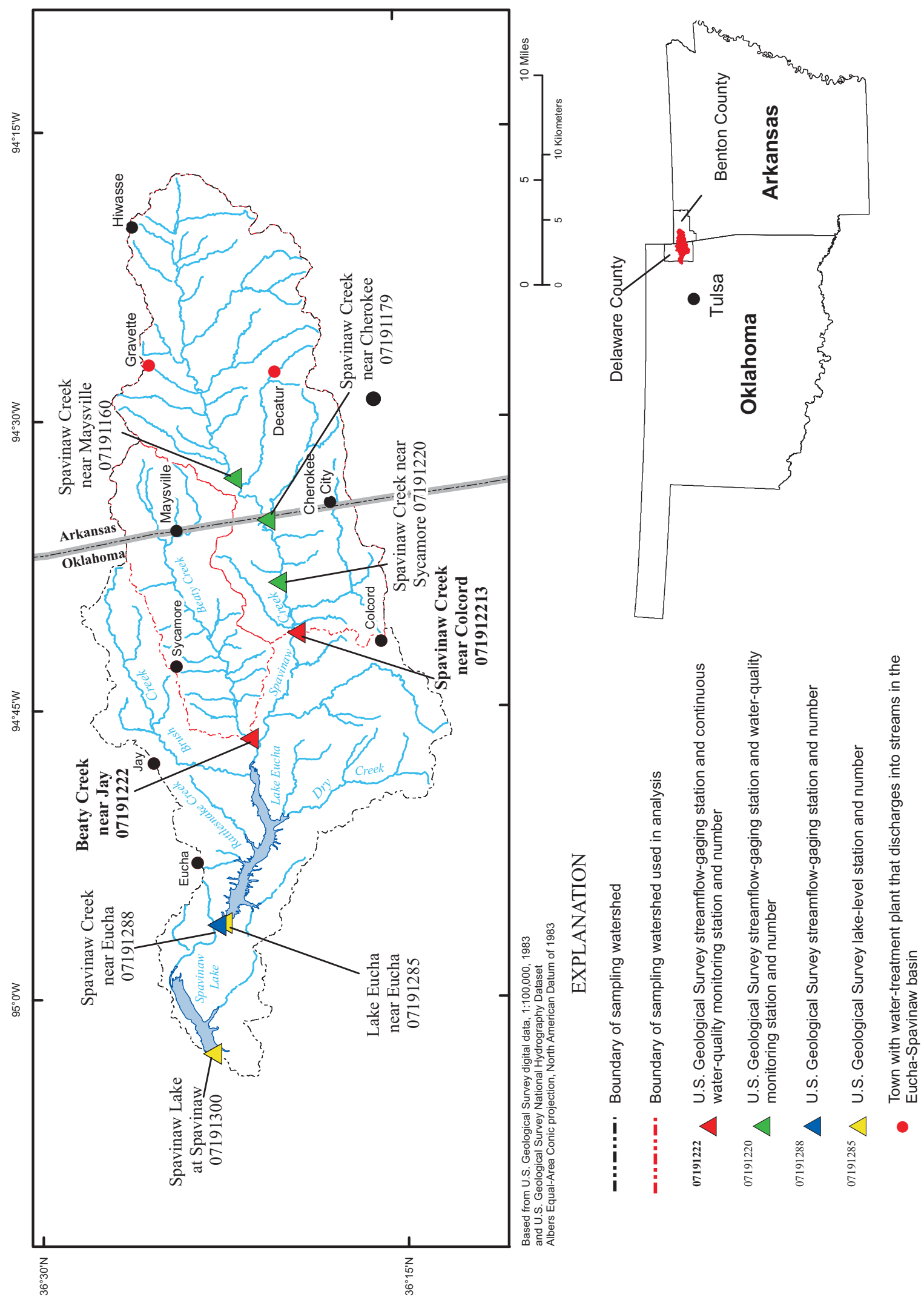


The City of Tulsa has received complaints of taste and odor in finished drinking water linked to the eutrophication of Lake Eucha and Spavinaw Lake (Oklahoma Conservation Commission, 2007). Eutrophication results when excess nutrients cause the growth of algae and other aquatic plants. Taste and odor compounds in drinking water result in increased treatment costs in the treatment plant and removal seldom succeeds completely (Walker and others, 1989); therefore, identifying the factors that drive the algal growth is imperative for mitigating taste-and-odor problems (Christensen and others, 2006). Monitoring has identified some key factors that may affect taste and odor. Nutrient loading to the reservoir is one of these key factors.

Water quality has been deteriorating in Lake Eucha and Spavinaw Lake because of increased phosphorus levels (City of Tulsa, 2007). Excess phosphorus in water can fertilize aquatic plants and cause excessive algal growth (fig. 2). Monitoring showed Lake Eucha and Spavinaw Lake to be impaired for fish most years because of low dissolved oxygen (City of Tulsa, 2007). Currently (2008), Lake Eucha and Spavinaw Lake are not supporting the Fish and Wildlife Propagation and Aesthetics designated uses (Oklahoma Department of Environmental Quality, 2002). The Spavinaw Creek and Beaty Creek basins are valuable for investigating the source of nutrients to the Lakes because of the basins size and the amount of water and nutrients supplied to Lake Eucha, relative to other tributaries. Storm and others (2002) estimated that Beaty Creek and Spavinaw Creek supply about 85 percent of the phosphorus entering Lake Eucha.

Although previous monitoring has indicated increasing phosphorus loads to Lake Eucha and Spavinaw Lake (Wagner and Woodruff, 1997), nutrient monitoring historically has been biased toward sampling during low flow (Tortorelli, 2006), possibly leading to underestimated historical nutrient loads in the basin. The collection of runoff samples and continuous water-quality monitoring could more accurately identify seasonal trends in selected water-quality properties and estimated nutrient mass transported in the Eucha-Spavinaw basin. Runoff water-quality samples were collected at Beaty Creek near Jay and Spavinaw Creek near Colcord, and three other water-quality collection sites in the Spavinaw basin, as part of a U.S. Geological Survey (USGS) study in 2002-2004 (Tortorelli, 2006). These data, in addition to fixed-period monthly sampling, were used to estimate average annual and seasonal nitrogen and phosphorus loads by using S-LOADEST (Insightful Corporation, 2005).

The collection of continuous water-quality data could help identify water-quality responses in the basin in real time and identify monthly and seasonal trends, which are valuable because high streamflow can have a substantial effect on chemical loads. Continuous water-quality data are valuable because concentration data from manually collected samples commonly are not sufficient for accurate load estimates (Christensen and others, 2000). In addition, continuous estimates of water-quality constituents in real time eliminate the waiting time inherent in laboratory analyses of chemical data, and may assist in early detection of water-quality issues in the watershed.

Collection of chemical constituents such as nitrogen and phosphorus can be labor-intensive and cost-prohibitive. As an alternative, water-quality properties measured by continuous, real-time water-quality monitors can be related to concentrations of these constituents in order to develop regression equations that can estimate constituent concentrations in real time. Instantaneous loads and yields may be computed from these estimated concentrations to gain a better perspective about the supply of nutrients to Lake Eucha and Spavinaw Lake in real time. Thus, a study was conducted by the USGS, in cooperation with the City of Tulsa to monitor nutrients and water properties at Spavinaw and Beaty Creeks, which flow into Lake Eucha and Spavinaw Lake.

Specific objectives of the study were to:

1. Enhance the current water-quality monitoring efforts in the Eucha-Spavinaw basin by implementing continuous, real-time water-quality monitoring at two existing continuous streamflow-gaging stationsSpavinaw Creek near Colcord (USGS station number 071912213) and Beaty Creek near Jay (USGS station number 07191222) (fig. 1) - to measure specific conductance, $\mathrm{pH}$, water temperature, turbidity, and dissolved oxygen; and

2. Develop regression models or equations by using water-quality properties (specific conductance and turbidity) and streamflow as surrogates for estimated total nitrogen and total phosphorus.

\section{Purpose and Scope}

This report describes the results of manually collected water samples from Spavinaw Creek and Beaty Creek and analyzed for total nitrogen and total phosphorus, and describes the continuous real-time water-quality data from monitors at Spavinaw Creek near Colcord and Beaty Creek near Jay and the benefits of continuous and real-time data. The report also describes the process for using the water-quality properties to estimate total nitrogen and total phosphorus concentrations. Separate sets of equations were created for the Spavinaw and Beaty streamflow-gaging stations to assist the City of Tulsa in determining the source of nutrients entering Lake Eucha and Spavinaw Lake.

Increasing interest in water quality makes this study of regional and national importance because this study shows how nutrient concentrations may be estimated continuously and in real time by using continuous monitoring of other surrogate properties. Once an equation is created between a surrogate and a nutrient, that equation can be used to estimate concentrations, loads, and yields for that site. The methods used in this study may be used for other sites in Oklahoma and the Nation to monitor future effectiveness of implemented land-resource best-management practices. Additionally, real- 


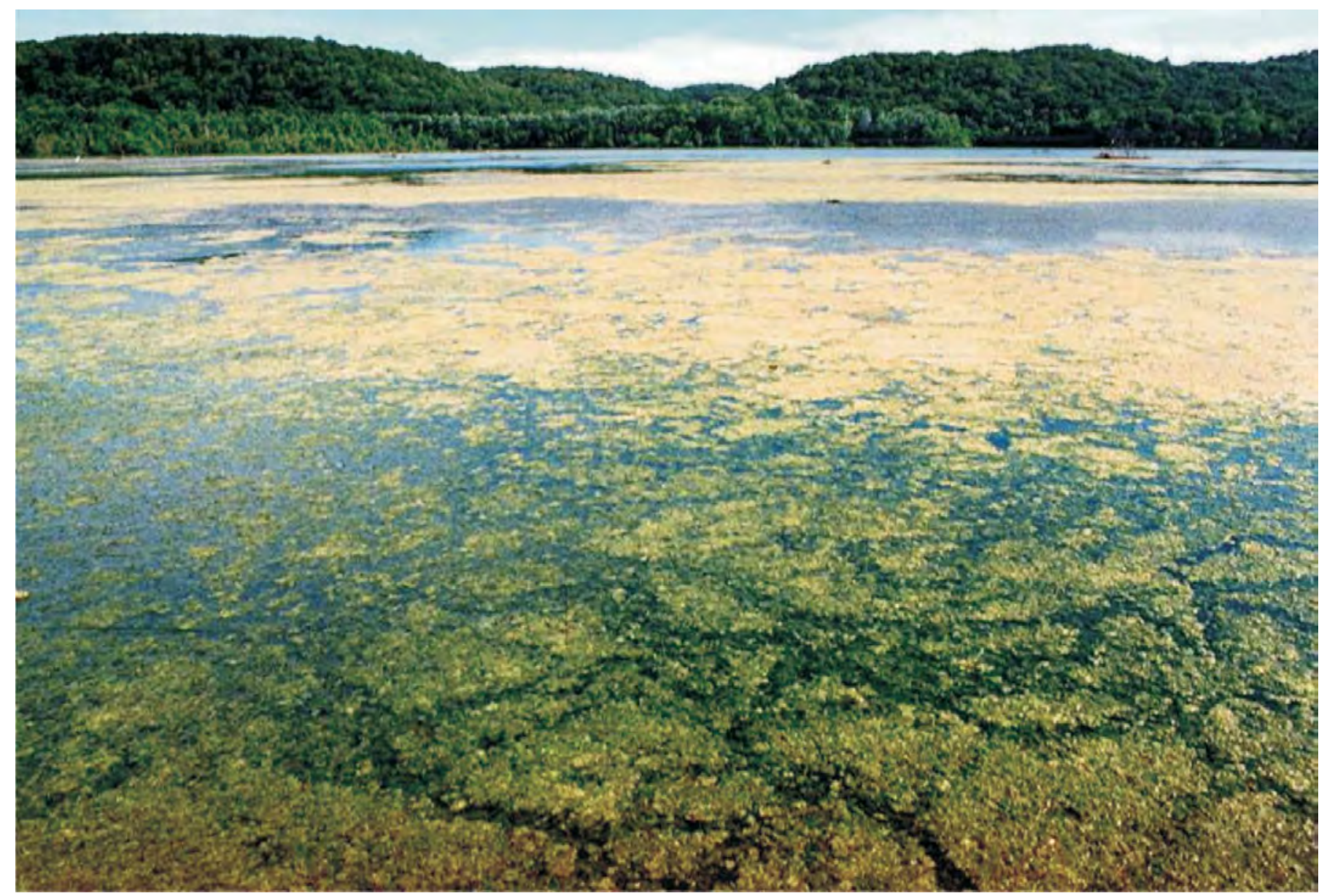

Figure 2. Algal bloom in Lake Eucha, July 11, 2001.

time monitoring can be used by water suppliers to anticipate treatment needs.

This report summarizes estimated nutrient concentrations and continuous water-quality monitoring in the EuchaSpavinaw basin during 2004-07. The information can be used to (1) assist in determining the effects of land-use practices on surface-water quality, (2) aid in supporting Federal, State, Tribal, and local efforts to improve water quality in the EuchaSpavinaw basin, (3) provide water-resources information that is useful to multiple parties for planning and operation through the dissemination of real-time hydrologic data, and (4) provide information that environmental officials, land managers, and land owners need to assess human health and ecosystem effects.

\section{Description of Study Area}

The meandering streams in the Eucha-Spavinaw basin have low gradients and wide valleys (Oklahoma Conservation Commission, 2007) and drain about 388 square miles $\left(\mathrm{mi}^{2}\right)$ in northeastern Oklahoma and northwestern Arkansas (Tortorelli, 2008). The water quality of the Eucha-Spavinaw basin is affected by various environmental factors. Physiography, geol- ogy, soil type, climate, land use, population, and water use can directly or indirectly affect water quality (Adamski and others, 1995). Therefore, a brief description of these environmental factors follows.

The Eucha-Spavinaw basin is in the Ozark Plateaus physiographic province (Fenneman, 1938) and the Springfield Plateau subdivision. The basin is underlain by limestone and cherty limestone of Mississippian age (Fenneman, 1938) and the Springfield Plateau aquifer (Adamski and others, 1995; Renken, 1998). Most of the soils in the Ozark Plateau have a high potential for nutrients and other dissolved constituents to be leached to the ground water and have a high potential for runoff to surface-water systems (Adamski and others, 1995). The karstic landscape of the Ozark Plateau was shaped by the dissolution of layers of soluble rock. Nitrate is easily transported to ground water in a karstic system through sinkholes and open fractures.

The mean annual temperature in the Eucha-Spavinaw basin is about $61^{\circ} \mathrm{F}$, January being the coldest month (average minimum temperature $27^{\circ} \mathrm{F}$ ) and July and August being the warmest months (average daytime temperature $92^{\circ} \mathrm{F}$ ) (National Oceanic and Atmospheric Administration, 2002). Mean annual precipitation is about 44 inches (1971-2000), and September is the month having the highest average precipitation 
(for the Spavinaw Temperature and Precipitation Station No. 168, which is located at the USGS streamflow gaging station number 07191300, Spavinaw Lake at Spavinaw, Oklahoma, National Oceanic and Atmospheric Administration, 2002).

Mean annual precipitation was 33.41 inches in 2005 , 35.75 inches in 2006, and 42.61 inches in 2007 (data from the Jay Weather Station, Oklahoma Climatological Survey, 2008a). Precipitation for all 3 years of the study was less than the mean annual precipitation reported for the nearby Spavinaw Weather Station (44 inches, 1971-2000, National Oceanic and Atmospheric Administration, 2002) and substantially less than the mean annual precipitation from 1971-2000 reported for the Jay Weather Station (46.5 inches, Oklahoma Climatological Survey, 2008b). Precipitation is essential because precipitation contributes to runoff, which may result in increased concentrations of sediment and nutrients reaching the stream. All three study years had less than average annual precipitation for the area.

The basin supports a variety of land uses (fig. 3), including agriculture (row crops, and pasture and hay) and forest and small urban areas throughout the watershed (Storm and others, 2002; DeLaune and others, 2006). The significance of agriculture in the basin is evident from the estimates of commercial fertilizer and manure applications for counties in the EuchaSpavinaw basin (table 1). Application of nutrients to crops and pasture as commercial fertilizer and manure can result in increased nutrients in surface and ground water. The total nutrient input from fertilizers is computed by adding commercial fertilizer to manure. Commercial fertilizer and manure applied is greater in Benton County, Arkansas, than in Delaware County, Oklahoma, (U.S. Department of Agriculture, 2002). Benton County also has a larger cattle and calf inventory, and more broilers and chickens sold when compared to Delaware County (table 1).

U.S. Census figures for 2006 show a population of 126,000 residents for Benton County, Arkansas, (U.S. Census Bureau, 2008). Delaware County, Oklahoma, had 37,000 residents in 2000 (2006 data not available; U.S. Census Bureau, 2008). The largest towns in the basin include Colcord, Decatur, Gravette, Jay, and Maysville (fig. 1). Ratios of surfacewater use to ground-water use are 41.1/8.8 in Benton County and 2.6/1.9 in Delaware County (in millions of gallons per day; Adamski and others, 1995). Most of this water is used for public supply and very little agricultural water use is reported for these two counties.

\section{Streamflow in the Eucha-Spavinaw Basin}

The combined drainage areas of Spavinaw and Beaty Creeks account for about 73 percent of the drainage basin of Lake Eucha. Several small tributaries contribute surface water and are possible additional sources of nutrients and other chemicals to the Lakes.

Streamflow and other water data in this report are compared and analyzed in terms of water year. The water year is a 12-month period that begins on October 1 and ends on Sep- tember 30. For example, the 2005 water year begins October 1, 2004, and ends on September 30, 2005.

Annual mean daily streamflow in the Eucha-Spavinaw basin was computed for Water Years 2005-2007. Streamflow was greater in Water Years 2005 and 2007 than in 2006 (table 2). During the period of real-time water-quality data collection (2005-2007), Beaty Creek near Jay was dry for 86 days.

Water Year 2006 was especially dry when compared to the period of record at Beaty Creek near Jay, water years 1999-2007 (Blazs and others, 1998-2007). The maximum daily mean streamflow during the period of record for the two sites are not comparable because the period of record for Spavinaw did not include 1999. When observing the period from October 2002 through September 2007, the maximum peak flow and highest daily mean flow in both streams was in 2004 and the minimum flow in Spavinaw Creek was in 2006. During the period of record, zero flow was recorded at Beaty Creek near Jay several times during summer (July through September). However, Beaty had extreme flows in 1999, which is reflected in the maximum daily mean streamflow for the period of record (table 2). Mean annual runoff often is used for comparing runoff characteristics between basins. Runoff is defined as the water that drains from the land into the stream or river channels after precipitation and is a function of precipitation amounts, topography, geology, soil moisture, and other factors (Adamski and others, 1995). Runoff can be computed by using the Base-Flow Index program (Institute of Hydrology, 1980a, 1980b; Wahl and Wahl, 1995). The mean fraction of annual total flow that is runoff, computed by using streamflow data for the period of record, is 44 percent at Spavinaw Creek near Colcord, and 68 percent at Beaty Creek near Jay. The lower runoff percentage at Spavinaw Creek may indicate the importance of ground-water inputs at this site.

\section{Sources of Nutrients}

Nitrogen and phosphorus loads are greater at Spavinaw Creek than Beaty Creek because of greater streamflow at Spavinaw Creek. However, the runoff component of the annual nitrogen and phosphorus loads from Beaty Creek was higher (85 percent and 98 percent, respectively; Tortorelli, 2006) than the runoff component of annual nitrogen and phosphorus loads from Spavinaw Creek (60 percent and 66 percent, respectively; Tortorelli, 2006). Total nitrogen delivered during runoff was substantially less for all Spavinaw Creek sites compared to the Beaty Creek near Jay site (table 3).

Nitrate and phosphorus tend to have different transport mechanisms in watersheds. Nitrate in the dissolved form often is transported in ground water. Total nitrogen and phosphorus tend to bind with organics or metals in soils and, therefore, are more conspicuous during runoff.

Sources of nutrients, including nitrogen and phosphorus, to the streams in the Eucha-Spavinaw basin include point and nonpoint sources. Point sources include wastewater-treatment plant discharges from urban areas (fig. 1) and septic systems. Spavinaw Creek (fig. 1) receives wastewater-treatment plant 


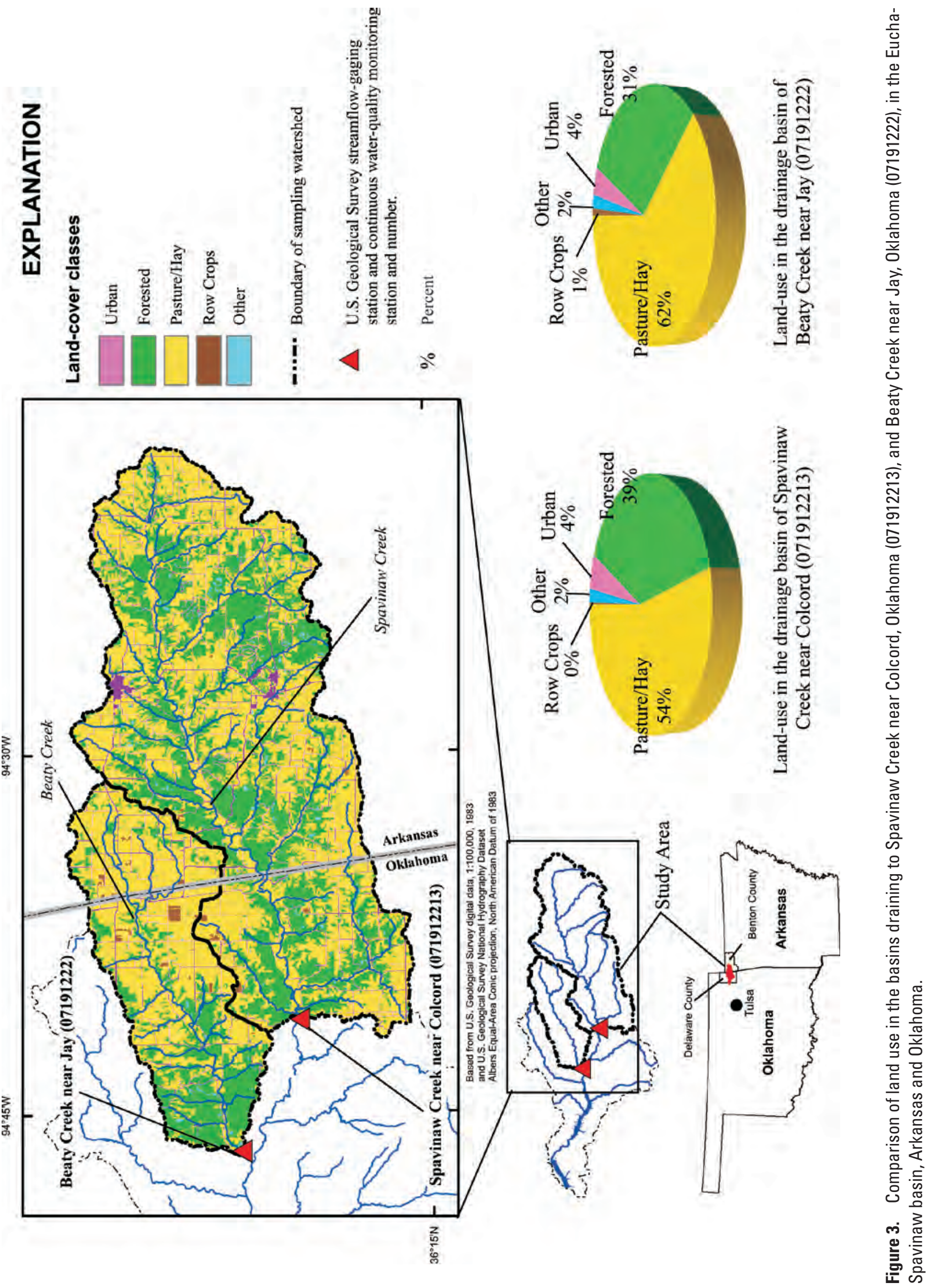


Table 1. Estimates of fertilizer application, number of cattle and calves, and number of broilers and other chickens sold for counties in the Eucha-Spavinaw basin, Arkansas and Oklahoma, 2002. (Data modified from U.S. Department of Agriculture, 2002).

\begin{tabular}{|c|c|c|c|c|c|c|c|c|c|}
\hline County & $\begin{array}{l}\text { Percentage } \\
\text { of Beaty } \\
\text { Creek } \\
\text { basin in } \\
\text { county }\end{array}$ & $\begin{array}{c}\text { Percentage } \\
\text { of } \\
\text { Spavinaw } \\
\text { Creek } \\
\text { basin in } \\
\text { county }\end{array}$ & $\begin{array}{l}\text { Land in } \\
\text { farms } \\
\text { (acres) }\end{array}$ & $\begin{array}{c}\text { Acres } \\
\text { treated } \\
\text { with } \\
\text { commercial } \\
\text { fertilizer }\end{array}$ & $\begin{array}{c}\text { Acres } \\
\text { treated } \\
\text { with } \\
\text { manure }^{1}\end{array}$ & $\begin{array}{c}\text { Total } \\
\text { acres } \\
\text { treated }\end{array}$ & $\begin{array}{l}\text { Percentage } \\
\text { of county } \\
\text { area treated } \\
\text { with } \\
\text { fertilizer }^{1}\end{array}$ & $\begin{array}{c}\text { Number } \\
\text { of cattle } \\
\text { and } \\
\text { calves }\end{array}$ & $\begin{array}{c}\text { Number of } \\
\text { broilers and } \\
\text { other } \\
\text { chickens } \\
\text { sold }\end{array}$ \\
\hline $\begin{array}{c}\text { Delaware, } \\
\text { Okla. }\end{array}$ & 67.4 & 23.5 & 282,106 & 53,185 & 21,346 & 74,531 & 26 & 74,719 & $37,154,935$ \\
\hline
\end{tabular}

Table 2. Streamflow statistics for continuous water-quality monitoring stations in the Eucha-Spavinaw basin, Arkansas and Oklahoma.

[all years are water years; $\mathrm{ft}^{3} / \mathrm{s}$, cubic feet per second]

\begin{tabular}{|c|c|c|c|c|c|c|c|}
\hline \multirow{2}{*}{$\begin{array}{l}\text { USGS site } \\
\text { number }\end{array}$} & \multirow{2}{*}{ Site name } & \multicolumn{4}{|c|}{ Annual mean daily streamflow $\left(\mathrm{ft}^{3} / \mathrm{s}\right)$} & \multicolumn{2}{|c|}{$\begin{array}{l}\text { Mean daily streamflow } \\
\text { for period of record }\left(\mathrm{ft}^{3} / \mathrm{s}\right)\end{array}$} \\
\hline & & 2005 & 2006 & 2007 & $\begin{array}{l}\text { Period of re- } \\
\text { cord (dates) }\end{array}$ & $\begin{array}{l}\text { Minimum } \\
\text { (date) }\end{array}$ & $\begin{array}{l}\text { Maximum } \\
\text { (date) }\end{array}$ \\
\hline 071912213 & $\begin{array}{l}\text { Spavinaw Creek near Colcord, } \\
\text { Okla. }\end{array}$ & 152.8 & 30.9 & 85.4 & $\begin{array}{c}106 \\
(2002-2007)\end{array}$ & $\begin{array}{c}8.7 \\
(7 / 29 / 2006)\end{array}$ & $\begin{array}{l}7,720 \\
(7 / 3 / 2004)\end{array}$ \\
\hline
\end{tabular}

${ }^{1}$ Zero flow reported on several occasions throughout the period of record.

Table 3. Drainage areas, periods of record, and total nitrogen and total phosphorus loads from water-quality stations in the EuchaSpavinaw basin, Arkansas and Oklahoma, 2002. (Modified from Tortorelli, 2006).

[USGS, U.S. Geological Survey; $\mathrm{mi}^{2}$, square miles; lb/yr, pounds per year]

\begin{tabular}{|c|c|c|c|c|c|c|c|}
\hline $\begin{array}{l}\text { USGS site } \\
\text { number }\end{array}$ & Site name & $\begin{array}{c}\text { Drainage } \\
\text { area } \\
\left(\mathrm{mi}^{2}\right)\end{array}$ & $\begin{array}{c}\text { Period } \\
\text { of } \\
\text { record }\end{array}$ & \multicolumn{2}{|c|}{ Mean annual nitrogen load } & \multicolumn{2}{|c|}{ Mean annual phosphorus load } \\
\hline 07191160 & Spavinaw Creek near Maysville, Ark. & 88.2 & $2002-2007$ & 521,000 & 64 & 20,000 & 93 \\
\hline 07191220 & Spavinaw Creek near Sycamore, Okla. & 133 & $1962-2007$ & 914,000 & 66 & 47,800 & 78 \\
\hline 071912213 & Spavinaw Creek near Colcord, Okla. ${ }^{1}$ & 163 & $2002-2007$ & $1,090,000$ & 61 & 50,700 & 80 \\
\hline 07191222 & Beaty Creek near Jay, Okla. ${ }^{1}$ & 59.2 & 1999-2007 & 257,000 & 85 & 27,000 & 98 \\
\hline
\end{tabular}

\footnotetext{
${ }^{1}$ Sites that have continuous water-quality monitors
} 
discharges; whereas, Beaty Creek does not (Tortorelli, 2006). The Arkansas towns of Decatur and Gravette are permitted wastewater-treatment facilities in the Eucha-Spavinaw basin (fig. 1).

Nonpoint sources include agricultural runoff, urban runoff (Oklahoma Water Resources Board, 2002), and runoff from soils. Agricultural activities contribute nutrients from the pasturing and confined feeding of livestock, and the use of synthetic fertilizers. Agricultural runoff may contain nutrients from inorganic phosphates added to soils as fertilizer and manure from animal production. A possible major source of nutrients in the Eucha-Spavinaw basin is the phosphorus-rich waste of commercial poultry growing operations (DeLaune and others, 2006). Poultry litter is used as a fertilizer for pastures in the basin (table 1). Geologic formations contain small amounts of phosphorus (Hem, 1992) and may contribute to phosphorus load.

\section{Acknowledgments}

The authors thank many people for their contributions to the data collection and station analysis presented in this report. There were numerous City of Tulsa personnel that participated in monthly water-quality sampling. There were numerous USGS personnel that participated in the runoff-event waterquality sampling and water-quality monitor maintenance. The entire Oklahoma Water Science Center Data Section and all three field offices added to the effort, but special thanks goes to the Tulsa Field Office for their contribution to the data collection and data processing.

\section{Methods}

\section{Data Collection and Analysis}

Continuously recording water-quality monitors (fig. 4) were installed at Spavinaw Creek near Colcord in November 2004 and Beaty Creek near Jay in March 2005. The waterquality properties measured by the monitors were specific conductance, $\mathrm{pH}$, water temperature, turbidity, and dissolved oxygen. The monitors were programmed to collect data readings every hour at Spavinaw Creek near Colcord, and every half-hour at Beaty Creek near Jay. These data were transmitted every 4 hours to the USGS offices in Tulsa.

Each sensor on the water-quality monitor has a certain range of operation. Specific conductance, $\mathrm{pH}$, water temperature, and dissolved oxygen sensors have wide ranges of operation that were not exceeded during the study and are not likely to be exceeded in the streams in the Eucha-Spavinaw basin. The turbidity sensors at these sites have maximum readings of about 1,200 formazin nephelometric units (FNU). This value was not exceeded on the in-stream monitors from October 2004 through September 2007. However, a value of

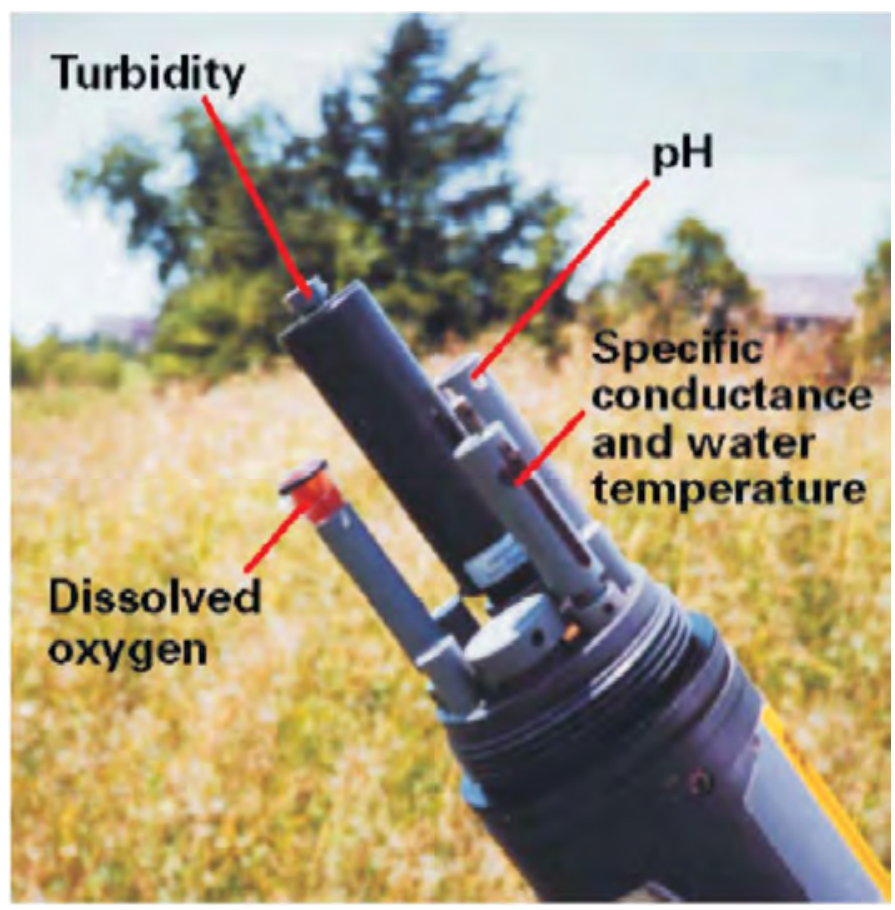

Figure 4. A water-quality monitor.

1,140 FNU was recorded on the in-stream monitor and a value of 1,480 FNU was recorded on the field monitor at the Spavinaw site during the study period and the range of the turbidity meters possibly will be exceeded in the future. The regression equations described in this report are only valid for the range of sensor values measured from October 2004 through September 2007.

The USGS manually collected samples during high flow by using depth and width integrating techniques in addition to the data collected by the in-stream water-quality monitors (U.S. Geological Survey, 2006). The City of Tulsa collected low-flow samples about once per month. The samples collected by the City of Tulsa generally were not depth and width integrated; these samples were collected from a single point near the midpoint of the stream.

Samples collected by using depth and width integrating techniques generally are more representative of stream-water quality than those samples collected from a single point (Ward and Harr, 1990); however, the water-quality monitor collected data from a single point in the stream. Therefore, differences between measurements in depth- and width-integrated water samples and measurements made by using the water-quality monitor existed, because of different sampling techniques.

The City of Tulsa provided the analytical services for all samples collected by USGS and City of Tulsa personnel. Samples were analyzed for water properties and nutrients including nitrite plus nitrate (U.S Environmental Protection Agency Method 353.2; O’Dell, 1993a), total Kjeldahl nitrogen (U.S Environmental Protection Agency Method 351.2; O'Dell, 1993b), and total phosphorus (U.S Environmental Protection Agency Method 365.2; U.S. Environmental Protection 
Agency, 1983), by using colorimetry methods. Total nitrogen was computed by adding nitrite plus nitrate and total Kjeldahl nitrogen values. Total nitrogen was computed by assuming that any concentration of nitrite plus nitrate or Kjeldahl nitrogen that was measured less than method detection limits were equal to 0.0 milligram per liter $(\mathrm{mg} / \mathrm{L})$. Total nitrogen and total phosphorus concentrations are listed in appendix 1 and appendix 2.

\section{Quality Assurance and Quality Control}

Quality assurance was achieved mainly through following a prescribed method of protocols and procedures as described in the National Field Manual (U.S. Geological Survey, 2006) for environmental samples and in Guidelines and Standard Procedures for Continuous Water-Quality Monitors (Wagner and others, 2006) for the monitors. Additionally, the collection and analysis of quality-control (QC) samples are mandated components of USGS water-quality field studies (U.S. Geological Survey, 2006) and compose a valuable part of the overall quality assurance of this project. The goal of QC sampling is to identify, quantify, and document bias and variability in data that result from the collection, processing, shipping, and handling of samples. Field blanks and field replicates were collected by the USGS at a rate of 10-20 percent of the number of environmental samples. The City of Tulsa collected QC samples at about the same rate.

Total nitrogen components (total Kjeldahl nitrogen and nitrite plus nitrate) were nondetectable in blank samples, and the median relative percent difference from sequential replicate analyses for the components of total nitrogen resulted in a difference of calculated total nitrogen that was acceptable at less than one percent. However, two blank samples analyzed for total phosphorus from the Beaty Creek site had values of 0.011 and $0.006 \mathrm{mg} / \mathrm{L}$. Those results indicate that some contamination resulted in the collection or processing of these samples and that potential contamination should be considered when evaluating the phosphorus data contained in this report. Concentrations of total phosphorus for this report ranged from 0.028 to $1.50 \mathrm{mg} / \mathrm{L}$. The duplicate total phosphorus analyses were acceptable with a median relative percent difference of 2.6.

The monitors were cleaned and each sensor calibration was checked during site visits. The water-quality monitors were inspected onsite by USGS personnel at least monthly to maintain calibration. Transmitted data were reviewed daily, and in the event of instrument malfunction or rapidly changing conditions, the monitors were cleaned and calibrated more often. Each monitor location was evaluated to determine if it needed to be moved because of changing streamflow or streambed conditions. Calibration procedures followed the suggested manufacturer's guidelines (Yellow Springs Instruments, Inc., 2002). Data corrections were occasionally applied based on calibration differences and changes in instrumentation response because of cleaning and general maintenance, in accordance with procedures detailed by Wagner and others (2006).

\section{Development of Regression Equations}

A system of estimating water-quality constituents was developed by the USGS Kansas Water Science Center. More information on this method can be found in Christensen and others (2000), Christensen (2001), and Rasmussen and Ziegler (2003). The following section is a brief explanation of those methods.

Total nitrogen or total phosphorus can be expressed in terms of a surrogate chemical property by using simple linear regressions (Helsel and Hirsch, 1992). Data from water-quality samples and the water-quality monitors at Spavinaw Creek and Beaty Creek were used to develop regression equations. These regression equations can be used to estimate instantaneous concentrations, daily loads, annual loads, and yields of total nitrogen and total phosphorus. The simplest regression equation is expressed as:

$y_{\mathrm{i}}=m x_{i}+b+e_{i}$

where

$$
\begin{aligned}
& y_{i} \quad \text { is the } i \text { th observation of the response } \\
& \text { (dependent) variable; } \\
& m \text { is the slope; } \\
& x_{i} \quad \text { is the } i \text { th observation of the explanatory } \\
& \text { (independent) variable; } \\
& b \quad \text { is the intercept; } \\
& e_{i} \quad \text { is the random error for the } i \text { th observation; } \\
& \text { and } \\
& i=1,2, \ldots \text { number of samples. }
\end{aligned}
$$

The parameters $m$ and $b$ were estimated from the dataset by using least-squares estimation (Helsel and Hirsch, 1992). A step-wise procedure (Ott, 1993, p. 656) and an overall method (Helsel and Hirsch, 1992, p. 312-314) were used. The possible explanatory variables included each of the sensor measurements of the water-quality monitor (specific conductance, $\mathrm{pH}$, water temperature, turbidity, and dissolved oxygen), streamflow, and time. If several acceptable equations were available, the one with the lowest PRESS statistic (Helsel and Hirsch, 1992, p. 248) and a low Mallow's Cp value, close to the number of parameters in the model, was selected (Draper and Smith, 1998, p. 332).

Common diagnostic statistics, in addition to the PRESS and Mallow's $\mathrm{Cp}$, which were used to select the equations, were used to evaluate the selected regression equations. These diagnostic statistics are the root mean square error (RMSE) and coefficient of determination $\left(R^{2}\right)$. RMSE is the square root of the mean square error (MSE). 
RMSE is calculated as follows:

$$
R M S E=\sqrt{\frac{\sum_{i=1}^{n}\left[y_{i}-E\left(y_{i}\right)\right]^{2}}{n-2}}
$$

where

$$
\begin{array}{cl}
y_{i} & \text { is the value of } \mathrm{y} \text { at the } i \text { th data point; } \\
E\left(y_{i}\right) & \text { is the estimated value of the } y \text { at the } i \text { th data } \\
\text { point; }
\end{array}
$$

The RMSE is determined for each equation to assess the variance between estimated and measured values.

The coefficient of determination, $R^{2}$ is the fraction of the variation explained by regression:

$R^{2}=1.0-(\operatorname{SSE} / \mathrm{SSy})$

The sum of squares of errors (SSE) is a dimensional measure of fitting $y$ on $x$ and is a measure of the unexplained variability. The sum of squares about the mean (SSY) represents the total variability (explained and unexplained) about the mean in $y$ values. SSE and $S S y$ are dimensional measures.

Graphical plots were constructed to examine the linearity of the relation between explanatory and response variables. Certain explanatory variables and response variables were transformed to convert all equations in this report to linear equations. Transformations (for example, base-10 logarithmic or power) of variables can eliminate curvature and simplify analysis of the data (Ott, 1993, p. 454). Retransformation of regression estimated concentrations can cause an underestimated chemical load when adding individual load estimates over a long period of time. The smearing bias-correction factor (Duan, 1983) can be used to correct for underestimation. Cohn and others (1989), Gilroy and others (1990), and Hirsch and others (1993) provide additional information on interpreting the results of regression-based load estimates.

In-stream monitor data were used in the regression analysis if USGS field instrument values were not available. USGS field instrument values were not available for samples collected by the City of Tulsa. For these samples, if an in-stream monitor value time did not correspond to the sample collection time, the in-stream values were interpolated. For example, at the Spavinaw Creek near Colcord site, which has hourly data, the nearest hourly values collected before and after the sample were used for interpolation. At times when turbidity values were changing rapidly, these turbidity values may have been interpolated as much as 3 hours before or 3 hours after the sample time depending on the variability of the conditions and to prevent interpolation among anomalous turbidity spikes. These spikes are more likely to happen during rapidly changing stream conditions such as streamflow events where turbidity is highly varied or localized stream disturbances that may result when bathing cattle kick up sediment in the stream upstream from the in-stream monitor. For Beaty Creek near Jay, a similar procedure was used, except that the in-stream monitor transmits every half hour instead of every hour. The field values and in-stream monitor values used in the regression analyses are provided in appendix 1 and appendix 2 .

\section{Uncertainty Associated with Regression-Based Estimates}

All the estimates in this report have some uncertainty. The uncertainty of these equations should be considered if the equations are to be used to estimate future concentrations or nutrient loads. The $R^{2}, R M S E$, and bias-correction factor all give an indication of uncertainty. In addition, the in-stream water-quality monitors have an upper limit of measurement regarding turbidity (about 1,200). This upper limit can cause underestimated concentrations and may have a substantial effect on load and yield estimates that use turbidity as a surrogate. However, except for one value of 1,480 FNU, turbidity values did not reach this upper limit during the study period.

Another limitation is the lack of intermediate flow and turbidity data available for the development of the regression equations. The USGS collected data during most streamflow peaks and, therefore, many samples were collected during the highest flows. City of Tulsa collected routine samples and, therefore, many samples were collected during low flows. However, samples were not consistently collected during intermediate ranges of streamflow. The calibration dataset may not be representative of the various future conditions for each stream because of the lack of samples during high and intermediate flow and turbidity. For example, the small number of high flow or high turbidity data available during 2004-2007 may not be representative of the various historic or future conditions in the stream. Average nutrient concentrations estimated by using 2004-2007 data may not be an accurate indication of conditions in future years because all three study years were below the average annual precipitation for the area.

Differences in water-quality monitor instrumentation, even of the same model type, can result in inconsistent readings among instruments. These differences may be caused by several factors, including monitor placement, differences in calibration, and age or wear of the instrument. Although quality assurance practices were performed to ensure that in-stream and field monitor values were accurate, differences often were observed. The use of water-property values from the same instrument may be preferable to develop the regression equation because the regression equations are being developed to estimate nutrient concentrations from water properties of the in-stream water-quality monitor. Either an interpolated value or the field instrument value was used in the regression because the in-stream values were not always available at the same time that a sample was collected. 


\section{Nutrient Concentrations in the Eucha- Spavinaw Basin}

\section{Measured Concentrations}

Streamflow, base flow, and runoff during the years of sample collection affected water-quality. For Spavinaw Creek and Beaty Creek daily mean streamflow from October 2004 through September 2007 generally was less than the mean daily streamflow during the period of record (water years 2001-2007 for Spavinaw Creek and 1999-2007 for Beaty Creek) (fig. 5). Streamflow measurements for water years 2005 to 2007 at Spavinaw Creek ranged from 11 to 5,700 cubic feet per second ( $\left.\mathrm{ft}^{3} / \mathrm{s}\right)$ and from 0 to $2,050 \mathrm{ft}^{3} / \mathrm{s}$ at Beaty Creek (table 4).

All three study years had below average annual precipitation for the area, and streamflow was especially low in Water Year 2006 (table 2). Average nutrient concentrations from October 2004 through September 2007, which were drier than others, may not be a good indication of conditions in future wetter years.

Water-quality samples were collected and analyzed for water properties and selected chemicals from October 2004 through September 2007 (table 4). These samples were collected throughout various streamflow conditions (fig. 5). Streamflow was low in 2006 at both stations, as evident from the graph, and no runoff samples were collected for nearly a year during 2005.

Water properties also were collected at the same time as manually collected water-quality samples in addition to the continuous in-stream water-quality monitor measurements. The turbidity was notably different between sites from October 2004 through September 2007 (table 4). The maximum turbidity at Spavinaw Creek was 1,480 FNU; whereas, the maximum turbidity at Beaty Creek was 450 FNU. Part of this difference is likely because of the lower streamflow at Beaty Creek. The maximum turbidity at Spavinaw Creek (1,480 FNU, collected on June 12, 2007, at 2:45 PM) measured in manually collected samples was higher than the maximum turbidity measured by the in-stream water-quality monitor (1,140 FNU, collected on July 1, 2005, at 2:00 PM) possibly because of the different instruments used to measure the turbidity. On June 12, 2007, when the concentration for the manually collected sample was 1,480 FNU, the in-stream monitor recorded 1,090 FNU (measured on the same date at 3:00 PM). This difference may be because of rapidly changing conditions between the time the sample was collected and the time the monitor recorded the turbidity value.

Seasonal variation in water quality was difficult to evaluate for some periods because of the number of samples collected and annual median nitrogen and phosphorus concentrations were similar for all 3 years. Total nitrogen concentrations from water samples collected at Spavinaw Creek ranged from 2.08 to $9.66 \mathrm{mg} / \mathrm{L}$; nitrogen concentrations were lower for water samples collected at Beaty Creek and ranged from 0.67 to $5.12 \mathrm{mg} / \mathrm{L}$. Total phosphorus concentrations ranged from 0.04 to $1.5 \mathrm{mg} / \mathrm{L}$ at Spavinaw Creek and from 0.028 to $1 \mathrm{mg} / \mathrm{L}$ at Beaty Creek. Land use practices likely have an effect on the nutrient concentrations at each site. Total nitrogen and phosphorus concentrations may be higher in the Spavinaw Creek basin, when compared with Beaty Creek basin, because of the number of chicken farms and the spreading of manure on pastures, which is greater in the Spavinaw basin (Storm and Others, 2002), as well as wastewater effluent which affects Spavinaw Creek (Tortorelli, 2006).

Water samples also were periodically analyzed for suspended sediment. The results are included in table 4 because of the relation of suspended sediment to turbidity. Suspended sediment represents suspended solid-phase material in a water sample (Gray and others, 2000); turbidity is the amount of opaqueness in a water sample, caused by suspended material.

\section{Regression-Estimated Concentrations and Continuous Water-Quality Monitoring}

Water properties can be measured directly and continuously by the in-stream water-quality monitor. However, in order to get continuous measures of total nitrogen and total phosphorus, concentrations were estimated on the basis of in-stream water-quality monitor measurements and regression analysis. Therefore, the relation between concentrations of nitrogen and phosphorus and water properties was determined, and regression equations were developed (table 5). $R^{2}, R M S E$, and bias-correction factor were calculated for each equation.

Through the least-squares regression process, certain explanatory variables were selected that have a significant relation to the response variable. However, an explanatory variable was included in the regression equation only if a physical basis or explanation necessitated inclusion. Each equation in table 5, is site specific (applies only to that site) and are valid only for the concentration ranges given in table 5. For example, the maximum turbidity value that can be used to predict total phosphorus at Beaty is 450 FNU compared to 1,480 FNU at Spavinaw Creek. More sampling is necessary to verify the Beaty total phosphorus model at higher turbidity values.

\section{Nitrogen Equations}

Nitrogen in water includes elemental nitrogen, ammonia, nitrite, or nitrate. Having an estimate for total nitrogen from the Spavinaw Creek and Beaty Creek sites is necessary for understanding the sources of nitrogen to Lake Eucha, where nitrogen can lead to excessive algal growth. A comparison of measured and regression-estimated nitrogen at Spavinaw and Beaty Creeks are substantially different (fig. 6).

The explanatory variables for estimated nitrogen in water from Spavinaw Creek were streamflow, turbidity, and specific conductance. Streamflow is positively related to nitrogen for Spavinaw Creek and Beaty Creek. A positive relation may 

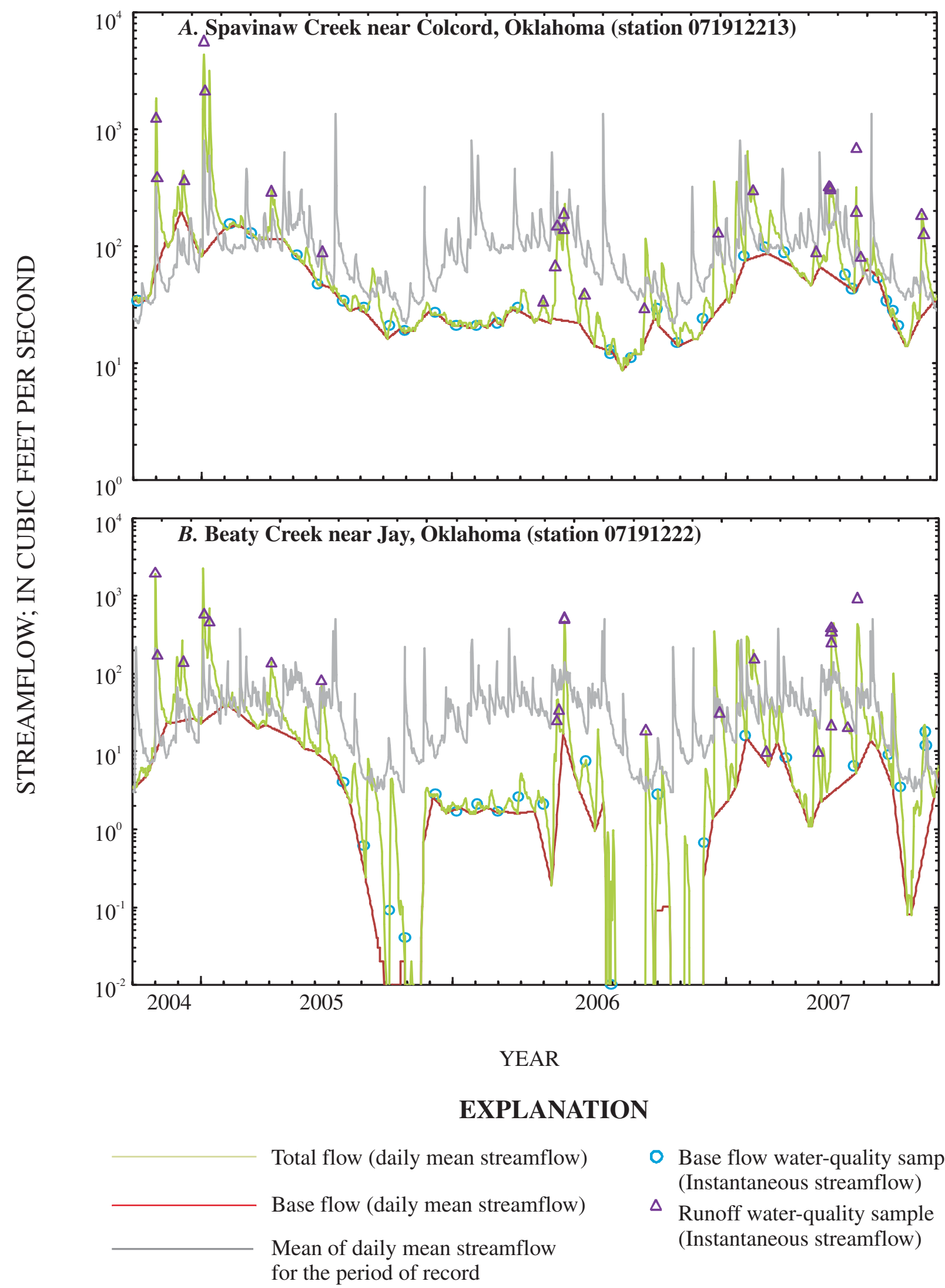

○ Base flow water-quality sample (Instantaneous streamflow)

$\Delta$ Runoff water-quality sample (Instantaneous streamflow)

Figure 5. Streamflow divided into total flow and base flow, mean of daily mean streamflow for the period of discharge record, and base-flow and runoff water-quality samples during Water Years 2005-2007 at (A) Spavinaw Creek near Colcord, Oklahoma, (period of record, 2002-2007) and (B) Beaty Creek near Jay, Oklahoma, (period of record 1999-2007). 
Table 4. Summary statistics for water-quality properties and constituents of manually collected water samples for Spavinaw Creek near Colcord, Oklahoma, and Beaty Creek near Jay, Oklahoma, October 2004-September 2007.

$\left[\mathrm{ft}^{3} / \mathrm{s}\right.$, cubic feet per second; $\mu \mathrm{S} / \mathrm{cm}$, microsiemens per centimeter at 25 degrees Celsius; ${ }^{\circ} \mathrm{C}$, degrees Celsius; FNU, formazin nephelometric units; mg/L, milligrams per liter]

\begin{tabular}{|c|c|c|c|c|c|}
\hline $\begin{array}{c}\text { Water } \\
\text { property or } \\
\text { constituent }\end{array}$ & Sample size & Minimum & Maximum & Mean & Median \\
\hline \multicolumn{6}{|c|}{ Spavinaw Creek near Colcord, Okla. (071912213) } \\
\hline Streamflow, $\mathrm{ft}^{3} / \mathrm{s}$ & 57 & 11 & 5,700 & 279 & 68 \\
\hline $\begin{array}{l}\text { Specific conductance, } \\
\mu \mathrm{S} / \mathrm{cm}^{1}\end{array}$ & 21 & 88 & 377 & 304 & 323 \\
\hline $\mathrm{pH}$, standard units & 21 & 6.4 & 7.8 & 7.4 & 7.4 \\
\hline $\begin{array}{l}\text { Water temperature, } \\
{ }^{\circ} \mathrm{C}\end{array}$ & 21 & 10.2 & 23.4 & 18.1 & 17.9 \\
\hline $\begin{array}{l}\text { Turbidity, } \\
\text { FNU }^{1}\end{array}$ & 44 & 0.3 & 1,480 & 47.6 & 1.1 \\
\hline $\begin{array}{l}\text { Dissolved oxygen, } \\
\mathrm{mg} / \mathrm{L}\end{array}$ & 21 & 6.2 & 11.1 & 8.8 & 8.2 \\
\hline Nitrogen, total, mg/L & 56 & 2.08 & 9.66 & 3.8 & 3.39 \\
\hline $\begin{array}{l}\text { Phosphorus, total, } \\
\text { mg/L }\end{array}$ & 52 & 0.04 & 1.5 & 0.15 & 0.082 \\
\hline $\begin{array}{l}\text { Suspended sediment, } \\
\mathrm{mg} / \mathrm{L}\end{array}$ & 18 & 1 & 1,810 & 120 & 9 \\
\hline \multicolumn{6}{|c|}{ Beaty Creek near Jay, Okla. (07191222) } \\
\hline Streamflow, $\mathrm{ft}^{3} / \mathrm{s}$ & 54 & 0 & 2,050 & 157 & 18.5 \\
\hline $\begin{array}{l}\text { Specific conductance, } \\
\mu \mathrm{S} / \mathrm{cm}^{1}\end{array}$ & 20 & 124 & 322 & 253 & 272 \\
\hline $\mathrm{pH}$, standard units & 20 & 6.8 & 7.7 & 7.4 & 7.4 \\
\hline $\begin{array}{l}\text { Water temperature, } \\
{ }^{\circ} \mathrm{C}\end{array}$ & 20 & 8 & 24.1 & 18.6 & 19.6 \\
\hline $\begin{array}{l}\text { Turbidity, } \\
\text { FNU }^{1}\end{array}$ & 43 & 0 & 450 & 19.1 & 0.7 \\
\hline $\begin{array}{l}\text { Dissolved oxygen, } \\
\mathrm{mg} / \mathrm{L}\end{array}$ & 20 & 5.3 & 11.9 & 8.2 & 8.1 \\
\hline $\begin{array}{l}\text { Nitrogen, total, } \\
\mathrm{mg} / \mathrm{L}\end{array}$ & 52 & 0.67 & 5.12 & 2.35 & 2.06 \\
\hline $\begin{array}{l}\text { Phosphorus, total, } \\
\text { mg/L }\end{array}$ & 50 & 0.028 & 1 & 0.118 & 0.053 \\
\hline $\begin{array}{l}\text { Suspended sediment, } \\
\text { mg/L }\end{array}$ & 18 & 2 & 664 & 93.4 & 8.5 \\
\hline
\end{tabular}

${ }^{1}$ Field values were measured at the time of sample collection and do not include interpolated values for specific conductance and turbidity that were used in regression equations (table 5). 


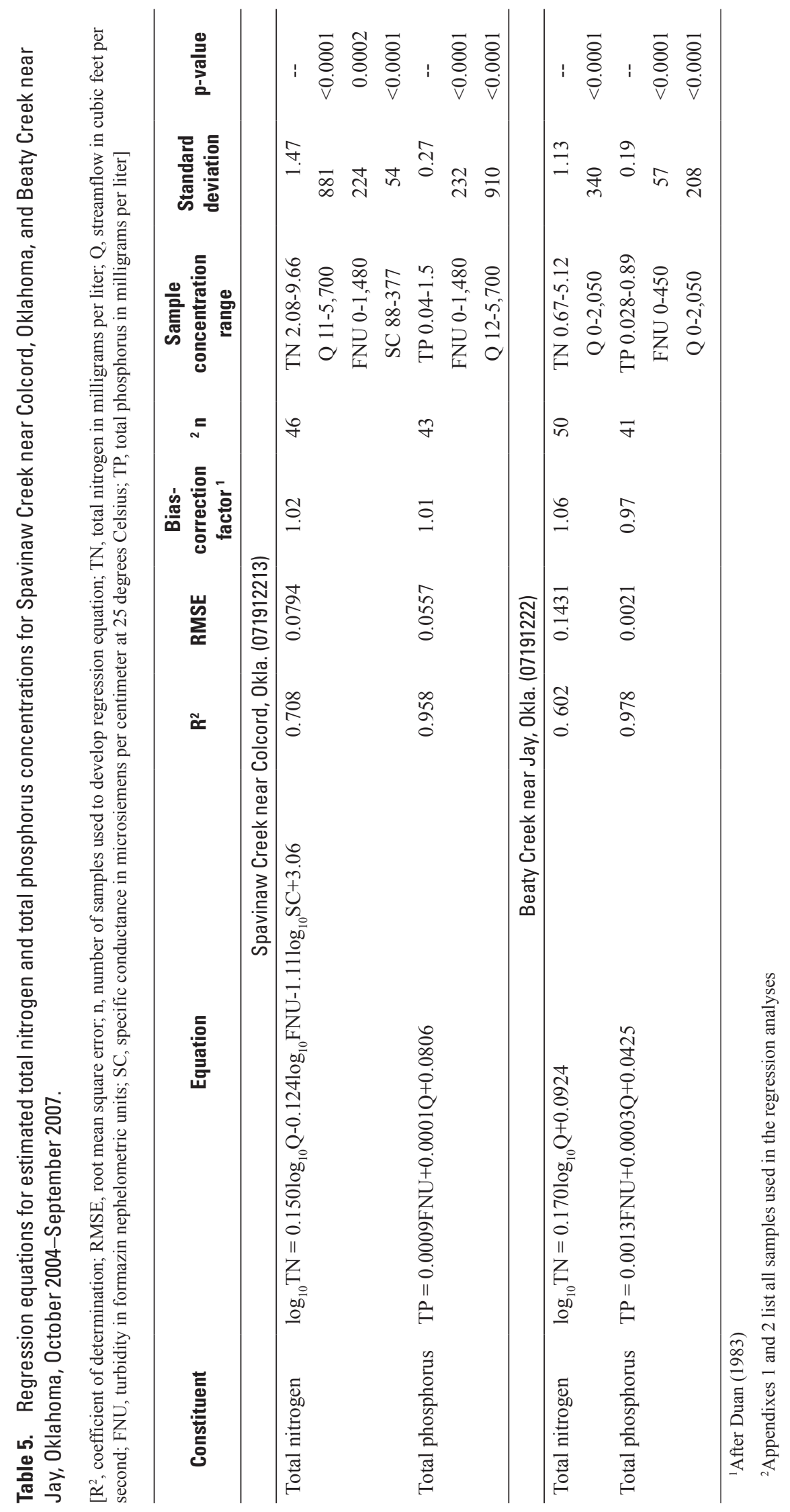



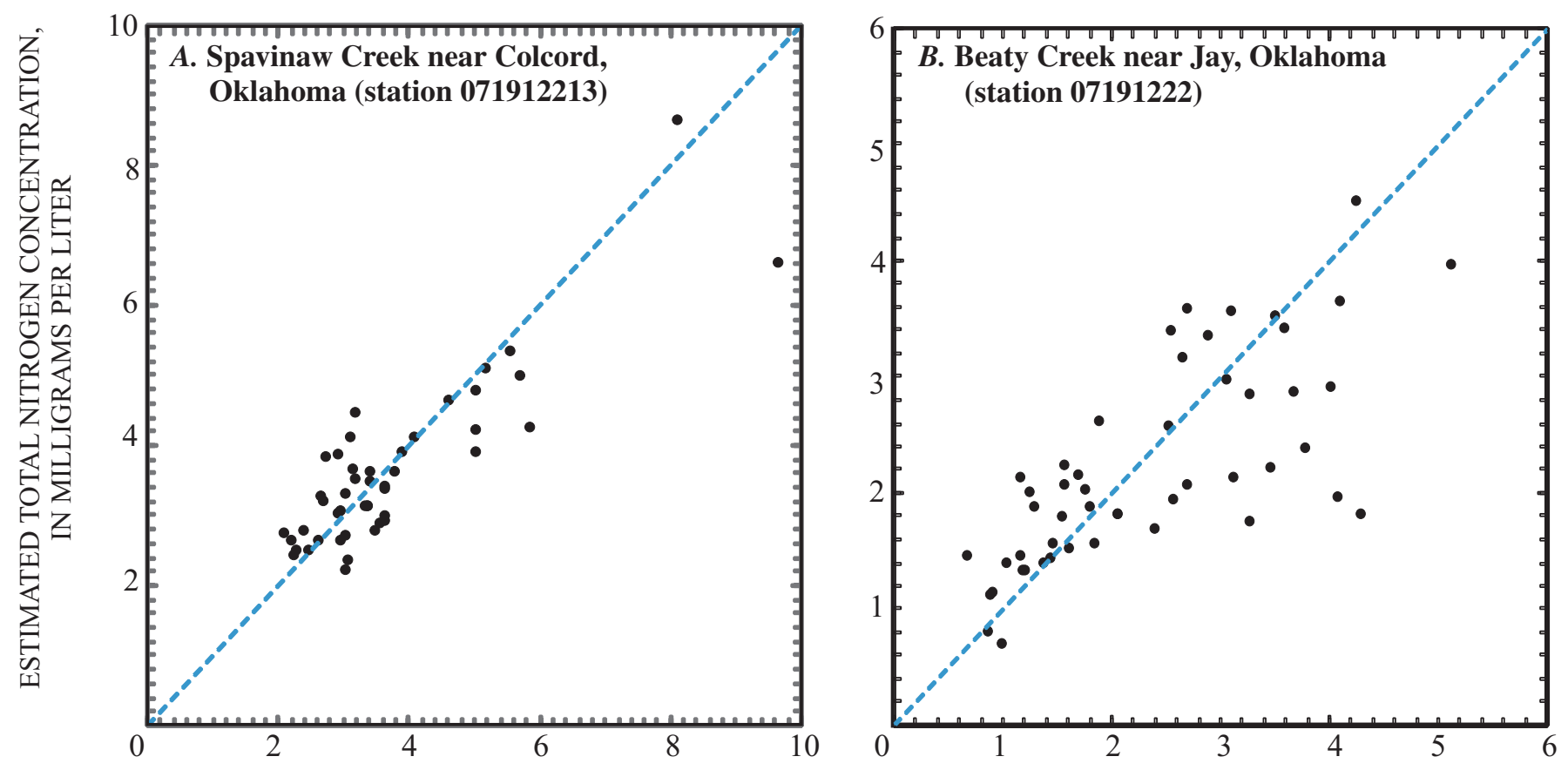

MEASURED TOTAL NITROGEN CONCENTRATION, IN MILLIGRAMS PER LITER

Figure 6. Comparison of measured and regression-estimated total nitrogen concentrations in water from $(A)$ Spavinaw Creek near Colcord, Oklahoma, and (B) Beaty Creek near Jay, Oklahoma.

indicate a nonpoint source of nitrogen. Turbidity is significantly related to total nitrogen at Spavinaw Creek, but not at Beaty Creek. Turbidity is, however, negatively related to total nitrogen. This negative relation was not expected and could be the result of a high concentration of dissolved forms of nitrogen in Spavinaw Creek. Nitrate is transported as a dissolved water-quality constituent (Hem, 1992). The negative relation could be explained if the total nitrogen in samples from Spavinaw Creek contained high concentrations of nitrate relative to the total nitrogen concentration. Unfortunately, none of the water samples analyzed for nitrogen species were filtered and, therefore, the concentrations of dissolved nitrite or nitrate are unavailable. Another possible explanation for the negative relation between total nitrogen and turbidity is the high leverage of the base-flow samples. When only the base-flow samples are plotted, the relation is obviously negative, perhaps because of the influence of nitrate from the wastewater-treatment plants at Decatur and Gravette and septic systems. When the four highest flow samples are plotted, the relation between turbidity and total nitrogen is positive.

Specific conductance is an explanatory variable for total nitrogen at the Spavinaw Creek site, but not at the Beaty Creek site. The negative relation between total nitrogen and specific conductance for Spavinaw Creek may indicate the importance of the influence of ground water at this site. Concentrations of dissolved constituents, as indicated by specific conductance, in surface water generally are highest during low flows because of the larger relative contributions of ground water (Adamski and others, 1995). Specific conductance in surface water generally is lowest during high flows because of dilution. The specific conductance at the Spavinaw Creek site may be necessary for defining the relation during low flow, when the Creek is gaining streamflow through ground-water contribution, as many streams do in northern Arkansas (Freiwald, 1987). Specific conductance varied seasonally - generally higher in summer and lower in winter. This variation can be used to describe the seasonal variation in concentrations of nitrogen in Spavinaw Creek, which in turn may reflect the seasonality of agricultural activities such as fertilizer application, or the seasonal influence of ground water discharges to the stream.

\section{Phosphorus Equations}

Phosphorus includes elemental phosphorus or dissolved orthophosphorus. Although nutrients are vital to growth and reproduction in an ecosystem, in excess amounts nutrients can interfere with these functions (Mueller and Helsel, 1996; Sharpley and Rekolainen, 1997). For example, elemental phosphorus may be toxic to aquatic organisms and may bioaccumulate in the same manner as mercury (U.S. Environmental Protection Agency, 1986).

Total phosphorus includes the dissolved (for example, organic phosphate) and particulate forms. The explanatory 
variables used for estimated total phosphorus at the Spavinaw and Beaty Creek sites were streamflow and turbidity. The two variables are related because turbidity is a measure of the amount of opaqueness caused by particulate matter in water and because phosphorus in water is mostly in the particulate form. The positive relation between total phosphorus and streamflow may indicate mostly nonpoint sources. When streamflow is high, runoff from the soils in the watershed is high and carries fertilizer, manure, and other farm chemicals to the stream. This phosphorus, in turn, continues to Lake Eucha providing nutrients for algae growth. Accelerated growth of algae can lead to eutrophication of a water body. Eutrophication is undesirable for many reasons including taste and odor, fish health, aesthetics, and infilling of reservoirs.

The total phosphorus equation for Beaty Creek was similar to, and had the same significant variables, as the equation for Spavinaw Creek. The range in estimated and measured phosphorus is not well distributed for Spavinaw Creek (fig. 7a) or Beaty Creek (fig. 7b). Total phosphorus includes the dissolved (for example, organic phosphate) and particulate forms. The Beaty equation is strongly influenced by one measurement at the high end. More high-flow and high-turbidity samples would help define the relation at the high end of the scale. However, the model coefficients did not change substantially when the high sample was omitted.

\section{Continuous Estimates of Total Nitrogen and Total Phosphorus}

The equations for nitrogen and phosphorus concentrations in table 5 were applied to the continuous data available during the 2005-2007 water years (figs. 8 and 9). The measured total nitrogen and total phosphorus concentrations also are shown in the figures.

Several of the measured total nitrogen concentrations for Spavinaw Creek plot above the estimated value during the winter (from about December through March) during 2006 and 2007. These differences may indicate that two equations are necessary to define total nitrogen for this site. Nitrogen has a negative relation to turbidity at low flows and a positive relation to turbidity at higher flows. Incorporating sine and cosine functions (as described in Helsel and Hirsch, 1992) in the equations might be possible with more runoff samples to accommodate the seasonality of total nitrogen. Seasonality functions have been applied successfully to estimate total nitrogen at other sites (Christensen, 2001; Ryberg, 2006). The sinusoidal curve in the total nitrogen data can be seen in 2005 and 2007 (fig. 8), but is not evident during 2006, when streamflow was considerably below normal. The use of specific con-
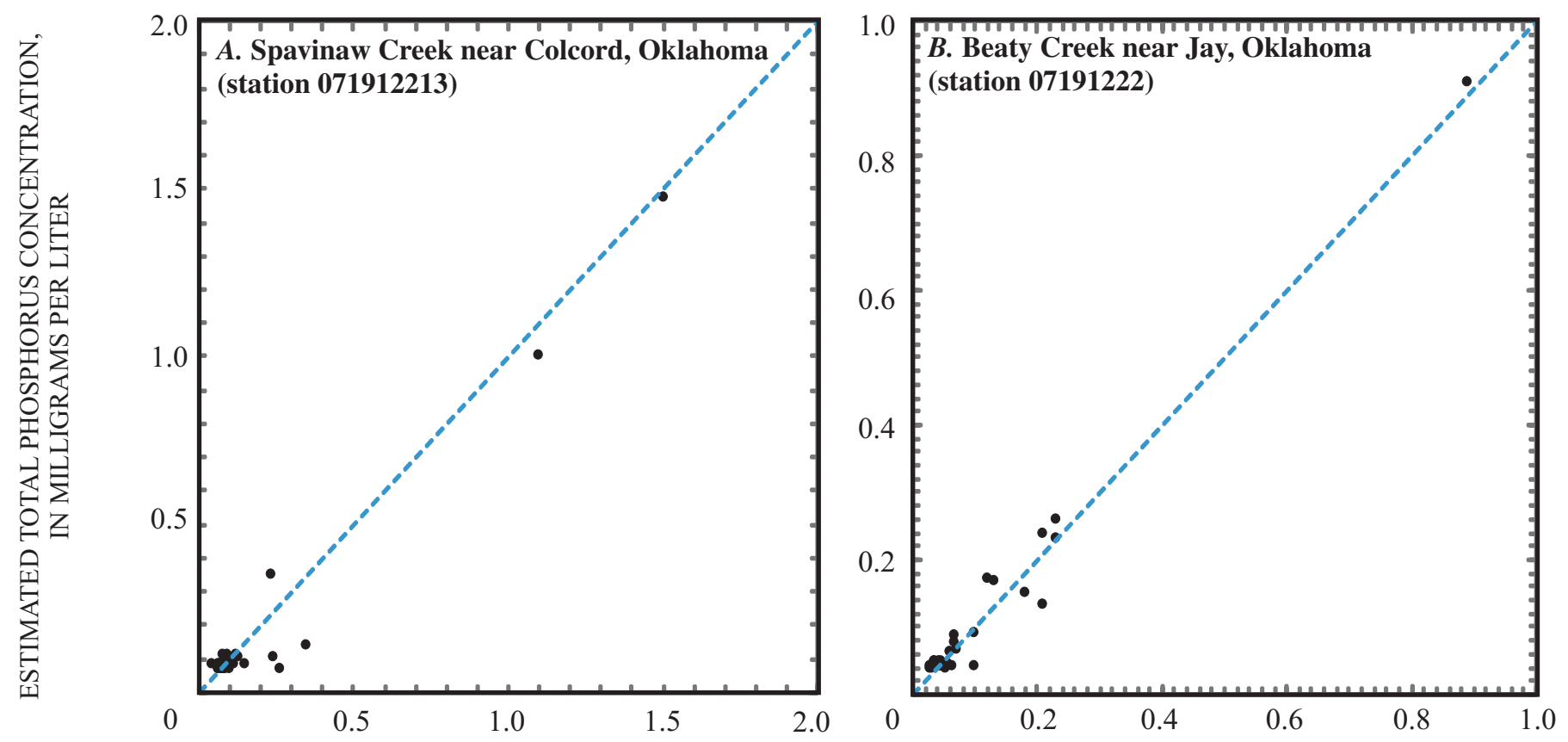

MEASURED TOTAL PHOSPHORUS CONCENTRATION, IN MILLIGRAMS PER LITER

Figure 7. Comparison of measured and regression-estimated total phosphorus concentrations in water from $(A)$ Spavinaw Creek near Colcord, Oklahoma, and (B) Beaty Creek near Jay, Oklahoma. 


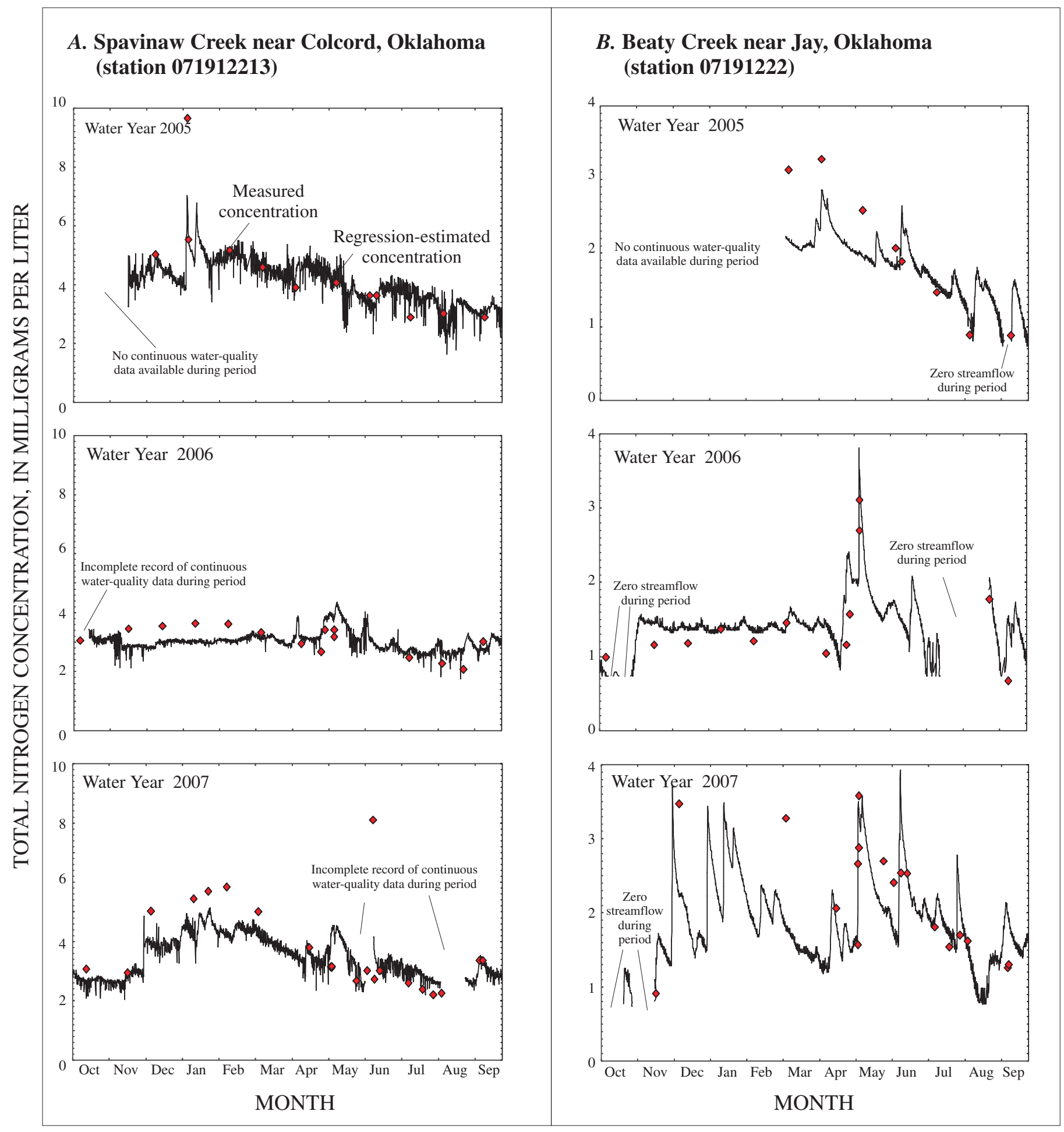

Figure 8. Comparison of measured and continuous regression-estimated total nitrogen concentrations in water from $(A)$ Spavinaw Creek near Colcord, Oklahoma, and (B) Beaty Creek near Jay, Oklahoma, Water Years 2005-2007. 


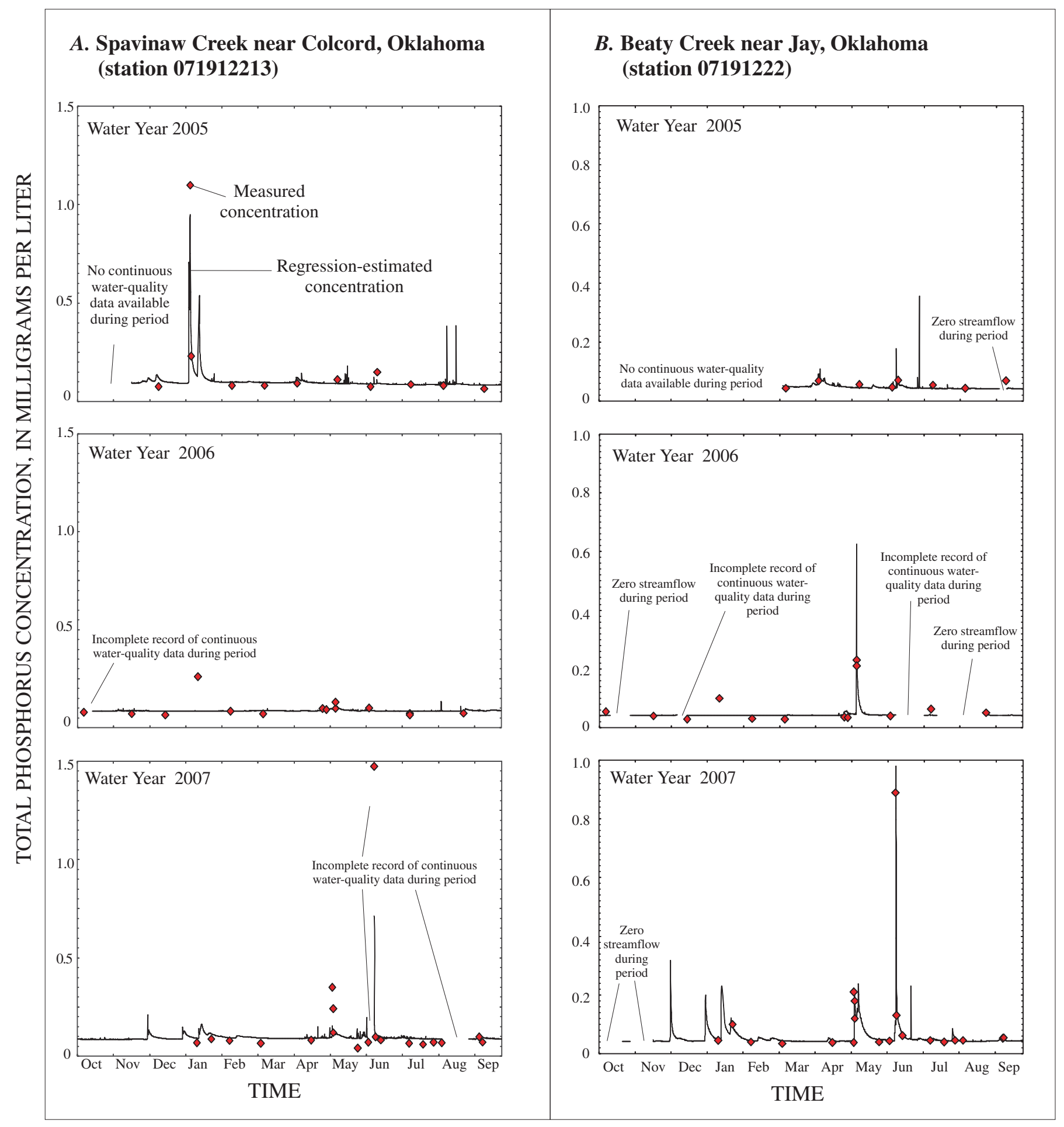

Figure 9. Comparison of measured and continuous regression-estimated total phosphorus concentrations in water from $(A)$ Spavinaw Creek near Colcord, Oklahoma, and (B) Beaty Creek near Jay, Oklahoma, Water Year 2005-2007. 
ductance in the equation may act as a surrogate for seasonality for the total nitrogen estimates at Spavinaw Creek.

A few measured values stand out from the estimated total nitrogen values (fig. 8). One measured total nitrogen concentration during water year $2007(8.11 \mathrm{mg} / \mathrm{L})$ appears to plot substantially higher than the estimated concentration; however, concentrations were not estimated for total nitrogen that day because of missing in-stream monitor data.

Differences between measured and estimated total phosphorus concentrations are small, with a few exceptions (fig. 9). Concentrations were very low in 2006 at Spavinaw Creek, where water samples were collected at low flow and low turbidity relative to other years. Figure 9 shows that few water samples were collected at high total phosphorus concentrations at either site during 2005-2007. Two high total phosphorus samples at Spavinaw Creek (in 2005 and 2007) and one high total phosphorus sample at Beaty Creek have a strong effect on the regression. The regression equations at both sites would benefit from more data collected during high flow, high turbidity, and high total phosphorus concentrations.

\section{Benefits of Continuous, Real-Time Water-Quality Monitoring and Future Work}

Data from water-quality monitors presented in this report are available continuously and in real time. Continuous monitoring enables identification of seasonal trends in selected water properties and chemical constituents, can be used to estimate the chemical mass transported to Lake Eucha and Spavinaw Lake, and can reveal diurnal patterns. Identification of concentrations during runoff events is especially valuable because high flows have such a substantial effect on chemical loads, and concentration data from manual samples often are not available. Water properties monitored on a continuous basis provide resource managers with real-time information on streamflow, specific conductance, and turbidity, as shown in figures 10 and 11. Specific conductance (fig. 10) and turbidity (fig. 11) have different responses than streamflow and can give a better indication of water quality at any given time than streamflow alone.

Tortorelli (2008) has estimated annual and seasonal loads for water-quality stations in the Eucha-Spavinaw basin by using linear regression relating calculated constituent loads, which is a product of streamflow and constituent concentration of manually collected samples, to daily mean streamflow, a time parameter in decimal years, and a seasonality parameter by using a S-LOADEST model. By using this model, the daily constituent load can be estimated, but the instantaneous loads cannot be calculated.

Loads are higher in Spavinaw Creek than in Beaty Creek presumably because of the higher rate of litter application in Spavinaw Creek basin than in Beaty Creek basin (Storm and others, 2002), in addition to wastewater effluent which affects Spavinaw Creek (Tortorelli, 2006). However, the runoff component of nutrient loads is higher from Beaty Creek, indicating nutrients may be primarily from nonpoint sources. Certain best management practices designed to address runoff may help mitigate the effect of nutrients from Beaty Creek basin on Lake Eucha and Spavinaw Lake. Loading changes from these implemented best management practices could be monitored by using continuous data to estimate instantaneous total nitrogen and phosphorus (as described in Christensen, 2001). Estimated constituent loads during streamflow events provide a resolution of load data that is not available by using other load calculation methods (such as the S-LOADEST model; Tortorelli, 2008) and, therefore, continuous water-quality monitoring of surrogates for the estimate of water-quality constituents in streamflow may increase the accuracy of load estimation.

Historically, nutrient loads may have been underestimated (Tortorelli, 2006). Continuous estimates of water-quality constituents may increase the accuracy of load estimates during runoff. More data need to be collected at both sites, however, in order to reduce the uncertainty of the surrogate regressions at higher nutrient concentrations. Improving the regressions in this range is necessary in order to reduce the uncertainty of nutrient loading because a large amount of nutrients are carried to Lake Eucha during runoff (Tortorelli, 2006). Reducing the uncertainty will increase the accuracy of the surrogate regressions for calculation of instantaneous loads, which could be used to calculate loads during longer-term periods, such as months, seasons, or years.

The methods described in this report also provide the data in real time. Previously, annual and seasonal loads were estimated for water-quality stations in the Eucha-Spavinaw basin by using linear regression to estimate daily constituent load (Tortorelli, 2006) but the instantaneous loads could not be calculated. The benefit of using water-quality surrogates as described in this report is that hourly loads can be calculated instantaneously in real time.

Constituent loads calculated by using real-time surrogate measurements may be necessary in the process of establishing and monitoring total maximum daily loads (TMDLs). A TMDL calculation is a calculation of the maximum mass of a constituent, such as total phosphorus, that a water body can receive and still meet water-quality standards. The increasing interest in TMDLs makes this method potentially valuable for immediate monitoring of implemented best management practices.

Real-time data are valuable when water resources have human health and ecosystem effects. Water suppliers can use real-time data to adjust treatment processes. Real-time data may be disseminated to allow recreationists to make water-use decisions.

Real-time monitoring is a potential tool for estimating taste-and-odor related compounds, such as an earthy smell (geosmin), chlorophyll-a, and Anabaena, in drinking water supplies (Christensen and others, 2006). Methods for designing taste-and-odor studies, with the possibility of using surrogate measures, have been developed (Graham and others, 2008), providing templates for possible future studies in Lake 


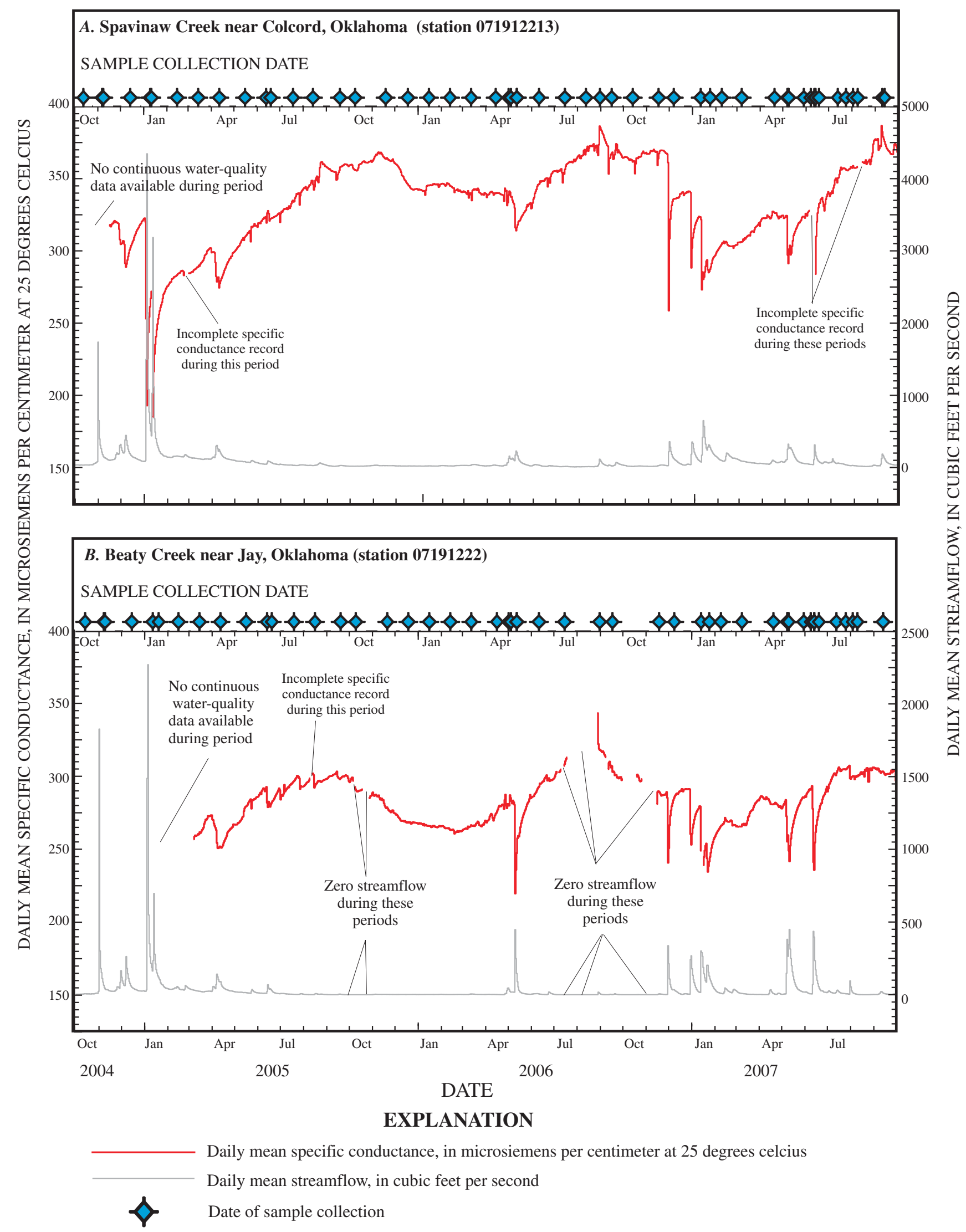

Figure 10. Daily mean specific conductance and daily mean streamflow at $(A)$ Spavinaw Creek near Colcord, Oklahoma, and (B) Beaty Creek near Jay, Oklahoma, Water Years 2005-2007. 


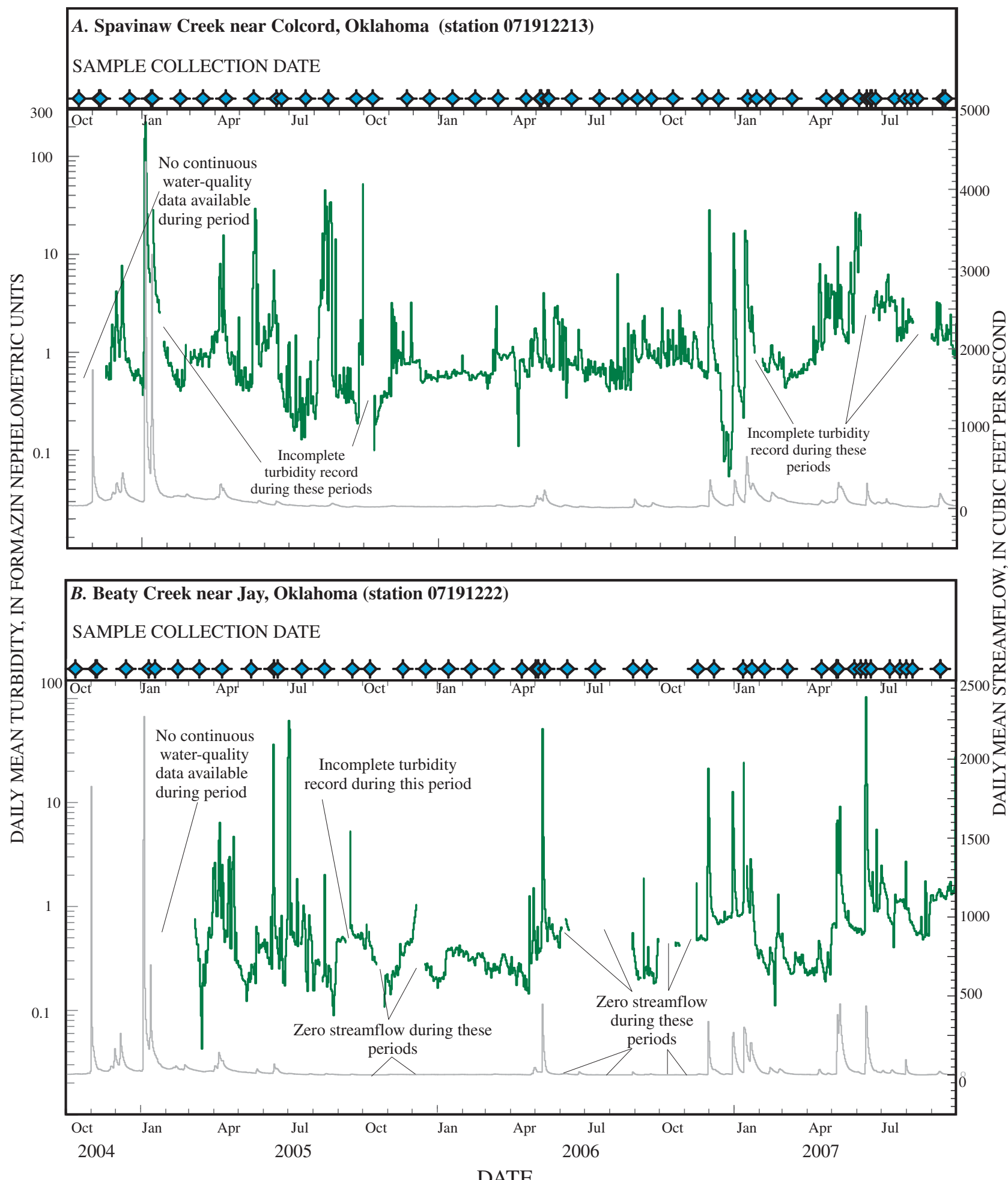

EXPLANATION

Daily mean turbidity, in formazin nephelometric units

Daily mean streamflow, in cubic feet per second

Date of sample collection

Figure 11. Daily mean turbidity and daily mean streamflow at $(A)$ Spavinaw Creek near Colcord, Oklahoma, and $(B)$ Beaty Creek near Jay, Oklahoma, Water Years 2005-2007. 
Eucha and Spavinaw Lake. Reliable tools such as the use of real-time surrogates for early detection and predictive models would allow resource managers time to respond more effectively to taste-and-odor events and minimize effects of these occurrences.

\section{Summary and Conclusions}

Lake Eucha and Spavinaw Lake serve as a water supply for the City of Tulsa, Oklahoma. Water quality has been deteriorating in Lake Eucha and Spavinaw Lake because of increased phosphorus levels. The drainage areas of Spavinaw and Beaty Creeks account for 73 percent of the drainage basin of Lake Eucha, the upstream reservoir in this two reservoir system. A previous study reported that Beaty and Spavinaw Creek supply an estimated 85 percent of the phosphorus entering Lake Eucha.

The basin supports a variety of land uses; however, the main land use is agriculture and forest. The agricultural land use consists of applying nutrients to crops and pasture as commercial fertilizer and manure. A possible major source of nutrients in the Eucha-Spavinaw basin is the phosphorus-rich waste of commercial poultry growing operations, which is used as a fertilizer for pastures.

The U.S. Geological Survey, in cooperation with the City of Tulsa, began a study to assist in determining the effects of land use practices on surface-water quality in the Spavinaw and Beaty Creek basins. Continuous in-stream water-quality monitors were installed at two existing continuous streamflow-gaging stations-Spavinaw Creek near Colcord, Oklahoma, and Beaty Creek near Jay, Oklahoma, in order to better characterize the nutrients entering Lake Eucha and Spavinaw Lake. The water-quality properties measured by the monitors were specific conductance, $\mathrm{pH}$, water temperature, turbidity, and dissolved oxygen. Water samples were analyzed for total nitrogen, total phosphorus, and suspended sediment concentrations.

Hydrologic conditions for Spavinaw Creek and Beaty Creek varied during the years of in-stream monitoring and for the period of record. Precipitation in the basin during the study period was less than for the period of record. Precipitation is essential because precipitation contributes to runoff, which may result in increased concentrations of sediment and nutrients reaching the stream. Streamflow measurements for water years 2005 to 2007 at Spavinaw Creek ranged from 11 to 5,700 cubic feet per second and from 0 to 2,050 cubic feet per second at Beaty Creek. Daily mean streamflow measurements during 2004 to 2007 at Spavinaw and Beaty Creeks were frequently lower than the mean daily streamflow for the period of record. During a period of nearly a year in 2005 no runoff samples were collected. All three study years had below average annual precipitation for the area, and streamflow was especially low in Water Year 2006. Average nutrient concentrations from October 2004 through September 2007, which were drier than others, may not be a good indication of conditions in future wetter years.

Total nitrogen concentrations from water samples collected at Spavinaw Creek ranged from 2.08 to 9.66 milligrams per liter; concentrations in water samples from Beaty Creek were less and ranged from 0.67 to 5.12 milligrams per liter. Total phosphorus concentrations ranged from 0.04 to 1.5 milligrams per liter at Spavinaw Creek and 0.028 to 1 milligram per liter at Beaty Creek.

Data from water-quality samples and the water-quality monitors at Spavinaw and Beaty Creeks were used to develop regression equations for total nitrogen and total phosphorus. Total nitrogen was related to streamflow, specific conductance, and turbidity; and total phosphorus was related to streamflow and turbidity for Spavinaw Creek. The total phosphorus equation for Beaty Creek was similar and had the same significant variables. However, the total nitrogen equation for Beaty Creek includes streamflow only as an explanatory variable. Spavinaw Creek possibly has more of an influence from ground water, because of the negative relation between nitrogen and specific conductance.

This method has limitations in estimating concentrations. First, the calibration dataset may not be representative of the various future conditions for each stream. For example, the small number of high flow or high turbidity data available during 2004-2007 may not be representative of the various historic or future conditions in the stream. Average nutrient concentrations estimated by using 2004-2007 data may not be an accurate indication of conditions in future years because all three study years were below the average annual precipitation for the area. The uncertainty of these equations should be considered if the equations are to be used to estimate future concentrations or nutrient loads.

The use of continuous, real-time monitoring and continued manual sample collection at Spavinaw Creek and Beaty Creek may be a useful tool for future monitoring of implemented best management practices. Spavinaw Creek has greater measured and estimated nutrient concentrations than Beaty Creek. However, the runoff component of nutrient loads is higher from Beaty Creek, indicating that much of the source for nutrients may be nonpoint. Therefore, certain best management practices may help mitigate the effect of nutrients from Beaty Creek basin on Lake Eucha and Spavinaw Lake.

Continuous, real-time monitoring is a potential tool for resource managers in determining the concentrations of nutrients and other chemicals. Instantaneous nutrient concentrations from the equations for the Beaty and Spavinaw sites may be used to estimate loads in order to better characterize the effect from these watersheds on Lake Eucha and Spavinaw Lake. The methods used in this study show promise for monitoring future effectiveness of implemented best management practices, development and monitoring of total maximum daily loads, early detection of taste-and-odor occurrences, and to anticipate treatment needs for water suppliers. 


\section{References Cited}

Adamski, J.C., Petersen, J.C., Freiwald, D.A., and Davis, J.V., 1995, Environmental and hydrologic setting of the Ozark Plateaus Study Unit, Arkansas, Kansas, Missouri, and Oklahoma: U.S. Geological Survey Water-Resources Investigations Report 94-4022, 69 p.

Blazs, R.L., Walters, D.M., Coffey, T.E., White, D.K., Boyle, D.L., and Kerestes, J.F., 1998, Water resources data, Oklahoma, water year 1997, Volume 1, Arkansas River Basin: U.S. Geological Survey Water-Data Report OK-97-1, $447 \mathrm{p}$.

Blazs, R.L., Walters, D.M., Coffey, T.E., Boyle, D.L., Kerestes, J.F., and Johnson, R.E., 1999, Water resources data, Oklahoma, water year 1998, Volume 1, Arkansas River Basin: U.S. Geological Survey Water-Data Report OK-98-1, 367 p.

Blazs, R.L., Walters, D.M., Coffey, T.E., Boyle, D.L., and Kerestes, J.F., 2000, Water resources data, Oklahoma, water year 1999, Volume 1, Arkansas River Basin: U.S. Geological Survey Water-Data Report OK-99-1, 364 p.

Blazs, R.L., Walters, D.M., Coffey, T.E., Boyle, D.L., and Wellman, J.J., 2001, Water resources data, Oklahoma, water year 2000, Volume 1, Arkansas River Basin: U.S. Geological Survey Water-Data Report OK-00-1, 382 p.

Blazs, R.L., Walters, D.M., Coffey, T.E., Boyle, D.L., and Wellman, J.J., 2002, Water resources data, Oklahoma, water year 2001, Volume 1, Arkansas River Basin: U.S. Geological Survey Water-Data Report OK-01-1, 349 p.

Blazs, R.L., Walters, D.M., Coffey, T.E., Boyle, D.L., and Wellman, J.J., 2003, Water resources data, Oklahoma, water year 2002, Volume 1, Arkansas River Basin: U.S. Geological Survey Water-Data Report OK-02-1, 375 p.

Blazs, R.L., Walters, D.M., Coffey, T.E., Boyle, D.L., and Wellman, J.J., 2004, Water resources data, Oklahoma, water year 2003, Volume 1, Arkansas River Basin: U.S. Geological Survey Water-Data Report OK-03-1, 394 p.

Blazs, R.L., Walters, D.M., Coffey, T.E., Boyle, D.L., and Wellman, J.J., 2004, Water resources data, Oklahoma, water year 2004, Volume 1, Arkansas River Basin: U.S. Geological Survey Water-Data Report OK-04-1, 231 p., available at http://pubs.usgs.gov/wdr/2004/wdr-ok-04-11.

Blazs, R.L., Walters, D.M., Coffey, T.E., Boyle, D.L., and Wellman, J.J., 2006, Water resources data, Oklahoma, water year 2005, Volume 1, Arkansas River Basin: U.S. Geological Survey Water-Data Report OK-05-1, 231 p., available at http://pubs.usgs.gov/wdr/2005/wdr-ok-05-17.
Christensen, V.G., 2001, Characterization of surface-water quality based on real-time monitoring and regression analysis, Quivira National Wildlife Refuge, south-central Kansas, December 1998 through June 2001: U.S. Geological Survey Water-Resources Investigations Report 01-4248, 28 p.

Christensen, V.G., Graham, J.L., Milligan, C.R., Pope, L.M., and Ziegler, A.C., 2006, Water quality and relation to taste-and-odor compounds in North Fork Ninnescah River and Cheney Reservoir, south-central Kansas, 1997-2003: U.S. Geological Survey Scientific Investigations Report 2006-5095, 43 p.

Christensen, V.G., Jian, Xiaodong, and Ziegler, A.C., 2000, Regression analysis and real-time water-quality monitoring to estimate constituent concentrations, loads, and yields in the Little Arkansas River, south-central Kansas, 1995-99: U.S. Geological Survey Water-Resources Investigations Report 00-4126, 36 p.

City of Tulsa, 2007, Lake Eucha and Spavinaw Lake Water Quality: City of Tulsa Environmental Operations, 93 p.

City of Tulsa, 2008, Water Supply Lakes_-Eucha and Spavinaw Watersheds: City of Tulsa, available on the World Wide Web, accessed February 18, 2008, at http://www.cityoftulsa. org/CityServices/Water/EuchaSpavinaw.asp.

Cohn, T.A., DeLong, L.L., Gilroy, E.J., Hirsch, R.M., and Wells, D.K., 1989, Estimating constituent loads: Water Resources Research, v. 25, no. 5, p. 937-942.

DeLaune, P.B., Haggard, B.E., Daniel, T.C., Chaubey, Indrajeet, and Cochran, M.J., 2006, The Eucha/Spavinaw phosphorus index - A court mandated index for litter management: Journal of Soil and Water Conservation, v. 61, no. 2, p. $96-105$.

Draper, N.R., and Smith, Harry, 1998, Applied regression analysis, (3d ed.): Hoboken, N.J., John Wiley and Sons, Inc., p. 332-334.

Duan, Naihua, 1983, Smearing estimate-A nonparametric retransformation method: Journal of the American Statistical Association, v. 78, no. 383, p. 605-610.

Fenneman, N.M., 1938, Physiography of the eastern United States: New York, McGraw-Hill, 714 p.

Freiwald, D.A., 1987, Streamflow gain and loss of selected streams in northern Arkansas: U.S. Geological Survey Water-Resources Investigations Report 86-4185, 4 sheets.

Gilroy, E.J., Hirsch, R.M., and Cohn, T.A., 1990, Mean square error of regression-based constituent transport estimates: Water Resources Research, v. 26, no. 9, p. 2,069-2,077. 
Graham, J.L., Loftin, K.A., Ziegler, A.C., and Meyer, M.T., 2008, Guidelines for design and sampling for cyanobacterial toxin and taste-and-odor studies in lakes and reservoirs: U.S. Geological Survey Scientific Investigations Report 2008-5038, 39 p.

Gray, J.R., Glysson, G.D., Turcios, L.M., and Schwarz, G.E., 2000, Comparability of suspended-sediment concentration and total suspended solids data: U.S. Geological Survey Water-Resources Investigations Report 00-4191, 14 p.

Helsel, D.R., and Hirsch, R.M., 1992, Statistical methods in water resources: New York, Elsevier, 522 p.

Hem, J.D., 1992, Study and interpretation of chemical characteristics of natural water (3d ed.): U.S. Geological Survey Water Supply Paper 2254, 263 p.

Hirsch, R.M., Helsel, D.R., Cohn, T.A., and Gilroy, E.J., 1993, Statistical analysis of hydrologic data, in Maidment, D.R., ed., Handbook of hydrology: New York, McGraw-Hill, Inc., p. $17.1-17.55$.

Insightful Corporation, 2005, S-Plus 7.0 for Windows Professional Developer Edition with Release 3.0 of the U.S. Geological Survey S-Plus library: Seattle, Washington.

Institute of Hydrology, 1980a, Low flow studies: Wallingford, Oxon, United Kingdom, Report No. 1, 41 p.

Institute of Hydrology, 1980b, Low flow studies: Wallingford, Oxon, United Kingdom, Report No. 3, p. 12-19.

Mueller, D.K., and Helsel, D.R., 1996, Nutrients in the Nation's waters - Too much of a good thing?: U.S. Geological Survey Circular 1136, 24 p.

National Oceanic and Atmospheric Administration, 2002, Monthly station normals of temperature, precipitation, and heating and cooling degree days 1971-2000: Climatography of the United States No. 81, 32 p.

O’Dell, J.W., ed., 1993a, Determination of nitrate-nitrite nitrogen by automated colorimetry: U.S. Environmental Protection Agency Method 353.2, 14 p.

O’Dell, J.W., ed., 1993b, Determination of total Kjeldahl nitrogen by semi-automated colorimetry: U.S. Environmental Protection Agency Method 351.2, 15 p.

Oklahoma Climatological Survey, 2008a, Monthly Summaries: Oklahoma Climatological Survey, accessed May 30, 2008, at http://climate.mesonet.org/coop.php.

Oklahoma Climatological Survey, 2008b, Delaware County Climate Summary: Oklahoma Climatological Survey, accessed May 12, 2008, at http://climate.mesonet.org county_climate/Products/QuickFacts/delaware.pd].
Oklahoma Conservation Commission, 2007, Lake Eucha/Lake Spavinaw Watershed Based Plan: Oklahoma City, Oklahoma, $54 \mathrm{p}$.

Oklahoma Department of Environmental Quality, 2002, The State of Oklahoma 2002 Water Quality Assessment Integrated Report: Oklahoma Department of Environmental Quality, accessed May 30, 2008, at www.deq.state.ok.us WQDnew/305b_303d/2002_integrated_report_final.pd], variously paged.

Oklahoma Water Resources Board, 2002, Water quality evaluation of the Eucha/Spavinaw Lake System: Oklahoma Water Resources Board, 145 p., accessed May 30, 2008, at http://www.owrb.ok.gov/studies/reports/eucha-spav.php.

Ott, R.L., 1993, An introduction to statistical methods and data analysis: Belmont, California, Duxbury Press, 1,051 p.

Rasmussen, P.P., and Ziegler, A.C., 2003, Comparison and continuous estimates of indicator bacteria in Kansas streams, in Proceedings of 2003 Spring Specialty Conference on Agricultural Hydrology and Water Quality, Kansas City, Missouri, May 12-14, 2003: American Water Resources Association, AWRA Technical Publication Series No. TPS-03-1, compact disc.

Renken, R.A., 1998, Ground water atlas of the United StatesSegment 5, Arkansas, Louisiana, Mississippi: U.S. Geological Survey Hydrologic Atlas 730-F, 28 p.

Ryberg, K.R., 2006, Continuous water-quality monitoring and regression analysis to estimate constituent concentrations and loads in the Red River of the North, Fargo, North Dakota, 2003-05: U.S. Geological Survey Scientific Investigations Report 2006-5241, 35 p.

Sharpley, A.N., and Rekolainen, S., 1997, Phosphorus in agriculture and its environmental conditions, in Tunney, H., Carton, O.T., Brookes, P.C., and Johnson, A.E., eds., Phosphorus loss from soil to water: New York, Cab International, p. 1-53.

Storm, D.E., White, M.J., and Smolen, M.D., 2002, Modeling the Lake Eucha basin using SWAT 2000: Oklahoma State University, Biosystems and Agricultural Engineering Department, $60 \mathrm{p}$.

Tortorelli, R.L., 2006, Nutrient concentrations, loads, and yields in the Eucha-Spavinaw basin, Arkansas and Oklahoma, 2002-2004: U.S. Geological Survey Scientific Investigations Report 2006-5250, 44 p.

Tortorelli, R.L., 2008, Nutrient concentrations, loads, and yields in the Eucha-Spavinaw basin, Arkansas and Oklahoma, 2002-2006: U. S. Geological Survey Scientific Investigations Report 2008-5174, 56 p. 
U.S. Census Bureau, 2008, U.S. Census Bureau Factfinder, accessed May 31, 2008, at http://factfinder.census.gov home/saff/main.html? lang=en.

U.S. Department of Agriculture, National Agricultural Statistics Service, 2002, 2002 Census of Agriculture: U.S. Bureau of Census, accessed May 26, 2008, at http://www.agcensus. usda.gov.

U.S. Environmental Protection Agency, 1983, Methods for chemical analysis of water and wastes, ( $2 \mathrm{~d}$ ed.): Method 365.2 U.S. Environmental Protection Agency, 552 p.

U.S. Environmental Protection Agency, 1986, Quality criteria for water, 1986: U.S. Environmental Protection Agency Report 440/5-86-001, unnumbered pages.

U.S. Geological Survey, 2006, Collection of water samples (ver. 2.0): U.S. Geological Survey Techniques of WaterResources Investigations, book 9, chap. A4, accessed May 19, 2008, at http://water.usgs.gov/owq/FieldManual/ chapter4/html/Ch4_contents.html

Wagner, Kevin and Woodruff, Scott, 1997, Phase 1 Clean Lakes Project Diagnostic and Feasibility Study of Lake Eucha: Oklahoma Conservation Commission, 69 p.
Wagner, R.J., Boulger, R.W., Jr., Oblinger, C.J., and Smith, B.A., 2006, Guidelines and standard procedures for continuous water-quality monitors - Station operation, record computation, and data reporting: U.S. Geological Survey Techniques and Methods 1-D3, 51 p. + 8 attachments; accessed April 10, 2006, at http://pubs.water.usgs.gov/tmld3.

Wahl, K.L., and Wahl, T.L., 1995, Determining the flow of Comal Springs at New Braunfels, Texas, in Proceedings of Texas Water, '95, A Component Conference of the First International Conference on Water Resources Engineering, American Society of Civil Engineers Symposium, San Antonio, Texas, August 16-17, 1995: American Society of Civil Engineers, p. 77-86.

Walker, W.W., Jr., Westerberg, C.E., Schuler, D.J., and Bode, J.A., 1989, Design and evaluation of eutrophication control measures for the St. Paul water supply: Lake and Reservoir Management, v. 5, no. 1, p. 71-83.

Ward, J.R., and Harr, Albert, 1990, Methods for collection and processing of surface-water and bed-material samples for physical and chemical analyses: U.S. Geological Survey Open-File Report 90-140, 71 p.

Yellow Springs Instruments, Inc, 2002, Environmental Monitoring 6-Series Systems Operations Manual. Variously paged, accessed May 27, 2008, at https://www.ysi.com/ portal/page/portal/YSI_Environmental/Support. 


\section{Appendixes}


Appendix 1. Water-quality data for Spavinaw Creek near Colcord, Oklahoma, water years 2005-2007, that were used to develop regression equations to estimate total nitrogen and total phosphorus.

[hhmm, hours and minutes; COT, City of Tulsa; USGS, U.S. Geological Survey; --, no data; $\mathrm{ft}^{3} / \mathrm{s}$, cubic feet per second; FNU, formazin nephelometric units; $\mu \mathrm{S} / \mathrm{cm}$, microsiemens per centimeter at 25 degrees Celsius; $\mathrm{mg} / \mathrm{L}$, milligrams per liter; $\mathrm{N}$, nitrogen; $\mathrm{P}$, phosphorus]

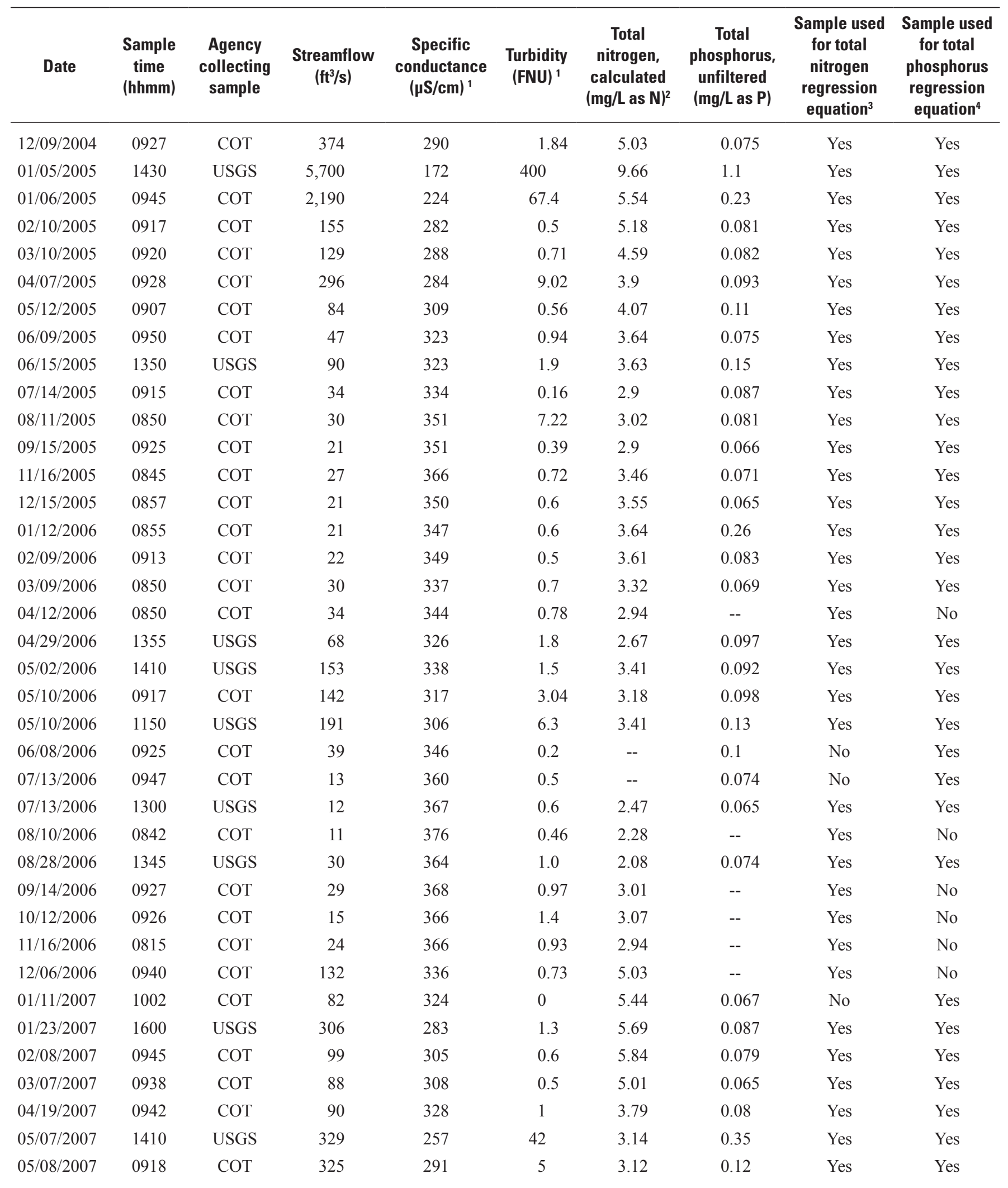


Appendix 1. Water-quality data for Spavinaw Creek near Colcord, Oklahoma, water years 2005-2007, that were used to develop regression equations to estimate total nitrogen and total phosphorus. - Continued

[hhmm, hours and minutes; COT, City of Tulsa; USGS, U.S. Geological Survey; --, no data; $\mathrm{ft}^{3} / \mathrm{s}$, cubic feet per second; FNU, formazin nephelometric units; $\mu \mathrm{S} / \mathrm{cm}$, microsiemens per centimeter at 25 degrees Celsius; $\mathrm{mg} / \mathrm{L}$, milligrams per liter; $\mathrm{N}$, nitrogen; $\mathrm{P}$, phosphorus]

\begin{tabular}{|c|c|c|c|c|c|c|c|c|c|}
\hline Date & $\begin{array}{l}\text { Sample } \\
\text { time } \\
\text { (hhmm) }\end{array}$ & $\begin{array}{l}\text { Agency } \\
\text { collecting } \\
\text { sample }\end{array}$ & $\begin{array}{c}\text { Streamflow } \\
\left(\mathrm{ft}^{3} / \mathrm{s}\right)\end{array}$ & $\begin{array}{c}\text { Specific } \\
\text { conductance } \\
(\mu \mathrm{S} / \mathrm{cm})^{1}\end{array}$ & $\begin{array}{l}\text { Turbidity } \\
\text { (FNU) }^{1}\end{array}$ & $\begin{array}{c}\text { Total } \\
\text { nitrogen, } \\
\text { calculated } \\
(\mathrm{mg} / \mathrm{L} \text { as } \mathrm{N})^{2}\end{array}$ & $\begin{array}{c}\text { Total } \\
\text { phosphorus, } \\
\text { unfiltered } \\
\text { (mg/L as } \mathrm{P} \text { ) }\end{array}$ & $\begin{array}{l}\text { Sample used } \\
\text { for total } \\
\text { nitrogen } \\
\text { regression } \\
\text { equation }\end{array}$ & $\begin{array}{l}\text { Sample used } \\
\text { for total } \\
\text { phosphorus } \\
\text { regression } \\
\text { equation } 4\end{array}$ \\
\hline 05/08/2007 & 1320 & USGS & 311 & 290 & 2.6 & 3.17 & 0.24 & Yes & Yes \\
\hline $05 / 29 / 2007$ & 1245 & USGS & 57 & 319 & 2 & 2.68 & 0.04 & Yes & Yes \\
\hline 06/13/2007 & 1315 & USGS & 199 & 286 & 6.0 & 2.73 & 0.096 & Yes & Yes \\
\hline 06/18/2007 & 1030 & USGS & 82 & 332 & 1.7 & 3.02 & 0.082 & Yes & Yes \\
\hline $07 / 12 / 2007$ & 0918 & COT & 53 & 355 & 3.32 & 2.6 & 0.064 & Yes & Yes \\
\hline $07 / 24 / 2007$ & 1000 & USGS & 34 & 360 & 1.1 & 2.38 & 0.06 & Yes & Yes \\
\hline 09/13/2007 & 0930 & $\mathrm{COT}$ & 129 & 377 & 1.4 & 3.37 & 0.071 & Yes & Yes \\
\hline
\end{tabular}

${ }^{1}$ If field measurement was unavailable, interpolation between hourly measurements from continuous water-quality monitor was used.

${ }^{2}$ Total nitrogen is calculated by adding unfiltered total Kjeldahl nitrogen and unfiltered nitrite plus nitrate analyses.

${ }^{3}$ Values were not used in total nitrogen regression equation if total nitrogen could not be calculated or if streamflow or turbidity data were not available or were equal to zero.

${ }^{4}$ Values were not used in total phosphorus regression equation if streamflow, turbidity, or total phosphorus data were not available. 
Appendix 2. Water-quality data for Beaty Creek near Jay, Oklahoma, water years 2005-2007, that were used to develop regression equations to estimate total nitrogen and total phosphorus.

[hhmm, hours and minutes; COT, City of Tulsa; --, no data; USGS, U.S. Geological Survey; $\mathrm{ft}^{3} / \mathrm{s}$, cubic feet per second; FNU, formazin nephelometric units; $\mu \mathrm{S} / \mathrm{cm}$, microsiemens per centimeterat 25 degrees Celsius; $\mathrm{mg} / \mathrm{L}$, milligrams per liter; $\mathrm{N}$, nitrogen; $\mathrm{P}$, phosphorus]

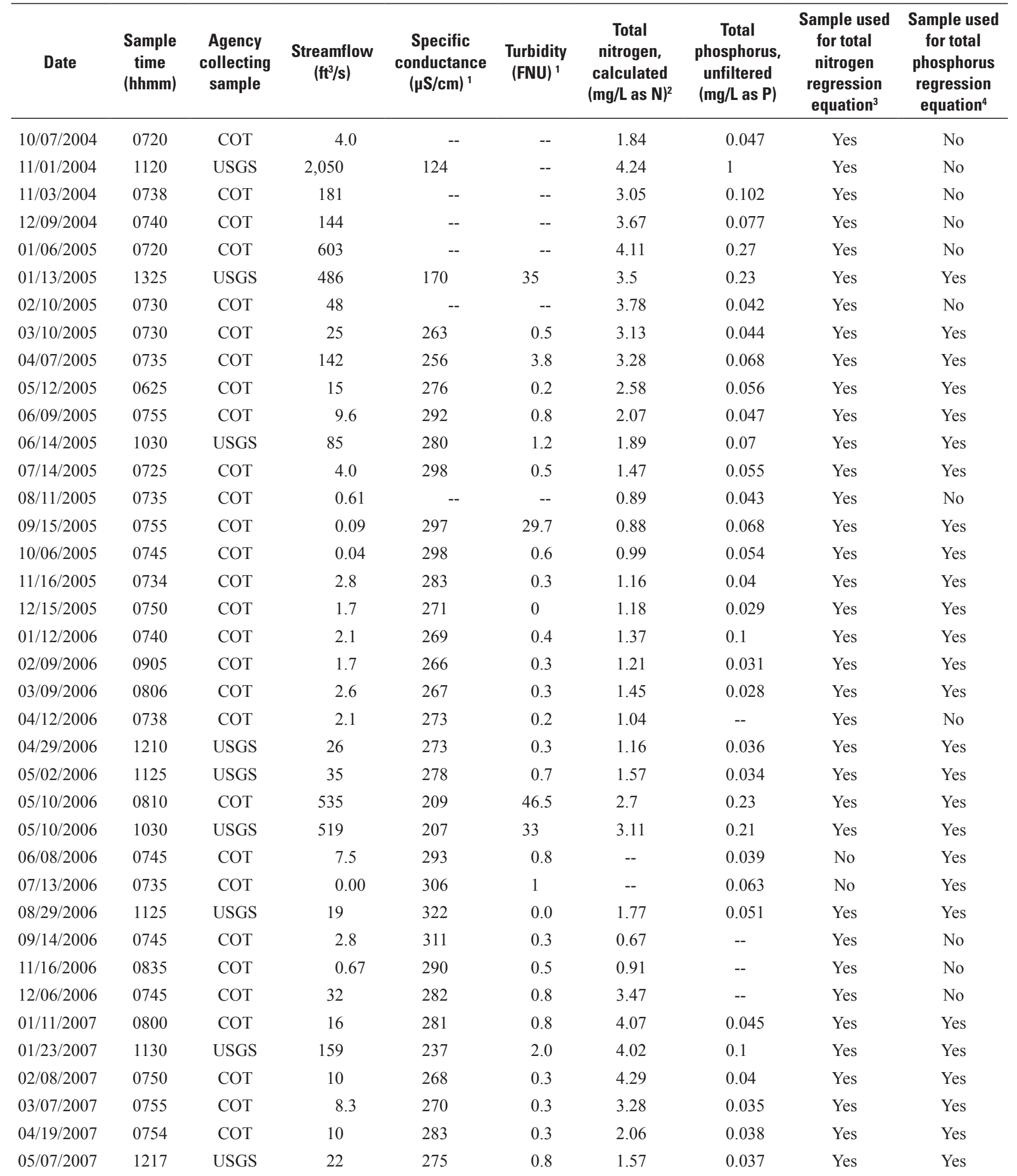


Appendix 2. Water-quality data for Beaty Creek near Jay, Oklahoma, water years 2005-2007, that were used to develop regression equations to estimate total nitrogen and total phosphorus. - Continued

[hhmm, hours and minutes; COT, City of Tulsa; --, no data; USGS, U.S. Geological Survey; $\mathrm{ft}^{3} / \mathrm{s}$, cubic feet per second; FNU, formazin nephelometric units; $\mu \mathrm{S} / \mathrm{cm}$, microsiemens per centimeterat 25 degrees Celsius; mg/L, milligrams per liter; $\mathrm{N}$, nitrogen; $\mathrm{P}$, phosphorus]

\begin{tabular}{|c|c|c|c|c|c|c|c|c|c|}
\hline Date & $\begin{array}{c}\text { Sample } \\
\text { time } \\
\text { (hhmm) }\end{array}$ & $\begin{array}{l}\text { Agency } \\
\text { collecting } \\
\text { sample }\end{array}$ & $\begin{array}{c}\text { Streamflow } \\
\left(\mathrm{ft}^{3} / \mathbf{s}\right)\end{array}$ & $\begin{array}{c}\text { Specific } \\
\text { conductance } \\
(\mu \mathrm{S} / \mathrm{cm})^{1}\end{array}$ & $\begin{array}{l}\text { Turbidity } \\
\text { (FNU) }{ }^{1}\end{array}$ & $\begin{array}{c}\text { Total } \\
\text { nitrogen, } \\
\text { calculated } \\
(\mathbf{m g} / \mathrm{L} \text { as } \mathbf{N})^{2}\end{array}$ & $\begin{array}{c}\text { Total } \\
\text { phosphorus, } \\
\text { unfiltered } \\
\text { (mg/L as P) }\end{array}$ & $\begin{array}{c}\text { Sample used } \\
\text { for total } \\
\text { nitrogen } \\
\text { regression } \\
\text { equation }\end{array}$ & $\begin{array}{c}\text { Sample used } \\
\text { for total } \\
\text { phosphorus } \\
\text { regression } \\
\text { equation }\end{array}$ \\
\hline $05 / 07 / 2007$ & 1635 & USGS & 258 & 261 & 13 & 2.66 & 0.21 & Yes & Yes \\
\hline 05/08/2007 & 0745 & COT & 406 & 254 & 7.6 & 3.58 & 0.12 & Yes & Yes \\
\hline 05/08/2007 & 1500 & USGS & 355 & 255 & 3.4 & 2.88 & 0.18 & Yes & Yes \\
\hline $05 / 29 / 2007$ & 1330 & USGS & 21 & 279 & 0.6 & 2.7 & 0.04 & Yes & Yes \\
\hline 06/07/2007 & 0800 & $\mathrm{COT}$ & 6.5 & 294 & 0.6 & 2.41 & 0.044 & Yes & Yes \\
\hline $06 / 12 / 2007$ & 1645 & USGS & 950 & 171 & 450 & 5.12 & 0.89 & Yes & Yes \\
\hline 06/13/2007 & 1120 & USGS & 390 & 239 & 8.7 & 2.54 & 0.13 & Yes & Yes \\
\hline 06/18/2007 & 1215 & USGS & 76 & 270 & 0.6 & 2.53 & 0.061 & Yes & Yes \\
\hline $07 / 12 / 2007$ & 0750 & $\mathrm{COT}$ & 12 & 305 & 0.73 & 1.81 & 0.046 & Yes & Yes \\
\hline $07 / 24 / 2007$ & 1130 & USGS & 9.1 & 302 & 0.3 & 1.54 & 0.039 & Yes & Yes \\
\hline 08/02/2007 & 1530 & USGS & 27 & 301 & 0.7 & 1.7 & 0.046 & Yes & Yes \\
\hline 08/09/2007 & 0800 & COT & 3.5 & 301 & 0.8 & 1.62 & 0.046 & Yes & Yes \\
\hline $09 / 12 / 2007$ & 1200 & USGS & 18 & 308 & 0.1 & 1.26 & 0.052 & Yes & Yes \\
\hline 09/13/2007 & 0735 & COT & 12 & 305 & 1.3 & 1.3 & 0.055 & Yes & Yes \\
\hline
\end{tabular}

${ }^{1}$ If field measurement was unavailable, interpolation between half-hour measurements from continuous water-quality monitor was used.

${ }^{2}$ Total nitrogen is calculated by adding unfiltered total Kjeldahl nitrogen and unfiltered nitrite plus nitrate analyses.

${ }^{3}$ Values were not used in total nitrogen regression equation if total nitrogen could not be calculated or streamflow data was not available or was equal to zero.

${ }^{4}$ Values were not used in total phosphorus regression equation if streamflow, turbidity, or total phosphorus data were not available.

Publishing support provided by:

Lafayette Publishing Service Center

For more information concerning this publication, contact:

Director, USGS Oklahoma Water Science Center

202 NW 66th St., Bldg. 7

Oklahoma City, OK 73116

(405) $810-4400$

Or visit the Oklahoma Water Science Center Web site at:

http://ok.water.usgs.gov 